\title{
Biomimetic building facades demonstrate potential to reduce energy consumption for different building typologies in different climate zones
}

\author{
Matthew Webb ${ }^{1}$
}

Received: 3 November 2020 / Accepted: 23 July 2021 / Published online: 18 August 2021

(c) The Author(s), under exclusive licence to Springer-Verlag GmbH Germany, part of Springer Nature 2021

\begin{abstract}
Greenhouse gas (GHG) emissions leading to anthropogenic global warming continue to be a major issue for societies worldwide. A major opportunity to reduce emissions is to improve building construction, and in particular the effectiveness of building envelope, which leads to a decrease in operational energy consumption. Improving the performance of a building's thermal envelope can substantially reduce energy consumption from heating, ventilation, and air conditioning while maintaining occupant comfort. In previous work, a computational model of a biomimetic building façade design was found to be effective in temperate climates in an office context. Through a case study example based on animal fur and blood perfusion, this paper tests the hypothesis that biomimetic building facades have a broader application in different building typologies across a range of climate zones. Using bioinspiration for innovation opens new ideas and pathways for technological development that traditional engineering design does not provide. This study exemplifies the process in a building façade, integrating a new form of insulation, heating and cooling. Methods of mathematical modelling and digital simulation methods were used to test the energy reduction potential of the biomimetic façade was tested in a set of operational applications (office, school, and aged care) and across different climate zones (tropical, desert, temperate, and cool continental). Results indicated that the biomimetic façade has potential to reduce energy consumption for all building applications, with the greatest benefit shown in residential aged care $(67.1 \%$ reduction). Similarly, the biomimetic building façade showed potential to reduce operational services energy consumption in all climate zones, with the greatest energy reductions achieved in the tropical (55.4\% reduction) and humid continental climates (55.1\% reduction). Through these results the hypothesis was confirmed suggesting that facades engineered to mimic biological functions and processes can improve substantially decrease building operational energy consumption and can be applied in different building classifications and different climate zones. These results would significantly decrease operational greenhouse gas emissions over the lifetime of a building and provide substantial savings in energy bills. Such facades can contribute to the further reduction in greenhouse gas emissions in a broad range of contexts in the built environment and other areas of technology and design. The flexibility and adaptability of biomimetic facades exemplify how biological strategies and characteristics can augment and improve performance in different environments, since the organisms that inspire innovation are already well-adapted to the conditions on earth. This study also exemplified a method by which other biomimetic building envelope features may be assessed. Further work is suggested to assess economic viability and constructability of the proposed facades.
\end{abstract}

Matthew Webb

matthew.webb@griffith.edu.au

1 School of Engineering and Built Environment, Griffith

University - Gold Coast Campus, Southport, QLD, Australia 


\section{Graphic abstract}

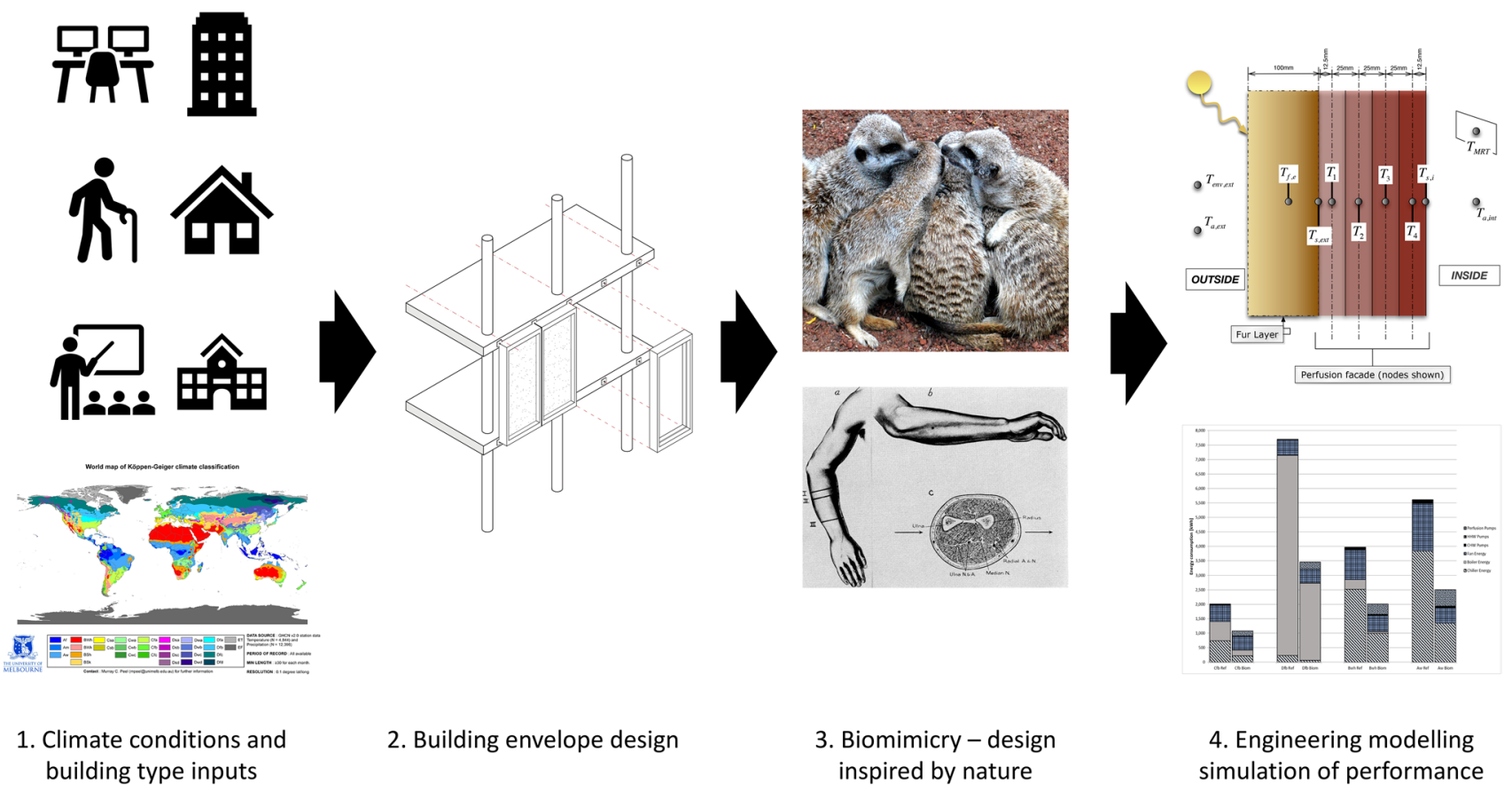

Keywords Biomimicry $\cdot$ Adaption $\cdot$ Façade $\cdot$ Bioheat transfer $\cdot$ Nature

\section{Abbreviations}

\section{Symbols-Latin}

A Area $\left(\mathrm{m}^{2}\right)$

$c_{\mathrm{p}} \quad$ Specific heat at constant pressure $\left(\mathrm{kJ} \mathrm{kg}^{-1} \mathrm{~K}^{-1}\right)$

$d_{\mathrm{f}} \quad$ Hair diameter $(\mathrm{m})$

$d_{\mathrm{t}} \quad$ Simulation timestep (s)

$d_{\mathrm{x}} \quad$ Simulation spatial step $(\mathrm{m})$

$F_{\mathrm{s}} \quad$ Characteristic describing interaction of fur with radiation $(-)$

$H \quad$ Height (m)

$h \quad$ Heat transfer coefficient $\left(\mathrm{W} \mathrm{m}^{2} \mathrm{~K}^{-1}\right)$

$K \quad$ Thermal conductivity $\left(\mathrm{W} \mathrm{m}^{-1} \mathrm{~K}^{-1}\right.$ )

$k_{\text {eff }} \quad$ Overall effective thermal conductivity of fur $\left(\mathrm{W} \mathrm{m}^{-1} \mathrm{~K}^{-1}\right.$ )

$\mathrm{L}_{\mathrm{f}} \quad$ Fur layer thickness (m)

$N_{\mathrm{f}, \mathrm{S}} \quad$ Non-dimensional parameter (apparent 'optical thickness' of fur in the solar spectrum) (-)

$P \quad$ Power delivered (W)

$Q, q \quad$ Heat transfer $\left(\mathrm{W} \mathrm{m}^{-2}\right)$

$q_{\mathrm{f}} \quad$ Heat transfer through fur $\left(\mathrm{Wm}^{-2}\right)$

$q_{\mathrm{e}, \mathrm{S}} \quad$ Solar radiation absorbed by skin/façade $\left(\mathrm{Wm}^{-2}\right)$

$R \quad$ Thermal resistance $\left(\mathrm{m}^{2} \mathrm{~K} \mathrm{~W}^{-1}\right)$

$S \quad$ Solar radiation $\left(\mathrm{Wm}^{-2}\right)$

$T \quad$ Temperature (K)
$T \quad$ Time (s)

$v \quad$ Velocity $\left(\mathrm{ms}^{-1}\right)$

$\dot{V} \quad$ Volumetric flow rate $\left(\mathrm{m}^{3} \mathrm{~s}^{-1}\right)$

w $\quad$ Width (m)

$\dot{w}_{\mathrm{b}} \quad$ 'Blood' perfusion rate $\left(\mathrm{m}^{3} \mathrm{~m}^{-3} \mathrm{~s}^{-1}\right)$

$X \quad H o r i z o n t a l$ dimension through façade (external surface $=0)(\mathrm{m}$

\section{Symbols-Greek}

$\alpha \quad$ Thermal diffusivity $\left(k / \rho c_{\mathrm{p}}\right)\left(\mathrm{m}^{-2} \mathrm{~s}^{-1}\right)$

$\alpha \quad$ Material absorptivity (-)

$\beta_{\mathrm{h}} \quad$ Extinction coefficient for fur (infrared spectrum) $(-)$

$\beta_{\mathrm{h}, \mathrm{S}} \quad$ Extinction coefficient for fur (solar spectrum)

$$
(-)
$$

$\varepsilon \quad$ Material emissivity (-)

$\rho \quad$ Density $\left(\mathrm{kg} \mathrm{m}^{-3}\right)$

$\theta_{\mathrm{f}} \quad$ Angle between normal to skin surface and hair

$$
\left(^{\circ}\right)
$$

$\theta_{\mathrm{S}} \quad$ Angle between normal to the skin and solar direction $\left(^{\circ}\right.$

\section{Subscripts}

1, 2, 3, 4 Finite difference node positions

a Air

amb Ambient

avg Average 
$b \quad$ 'Blood' (biomimetic façade cooling/heating fluid)

cond Conduction

conv Convection

d Diffuse

$e \quad$ External

eff Effective

env Environmental

$f \quad$ Fur

$g \quad$ Ground

$i \quad$ Internal

$i, j, n \quad$ Summation indices

lw Long wave

rad Radiation

$\mathrm{RC} \quad$ Combined radiation and conduction

$s \quad$ Surface

$S \quad$ Solar

skin Skin

sky $\quad$ Sky

surf Surf

$T \quad$ Total

$t \quad$ 'Tissue' (biomimetic façade material)

$u \quad$ Unitised façade element

w Wall

\section{Superscripts}

$n \quad$ Current finite difference timestep

\section{Introduction}

There is currently an urgent need to reduce greenhouse gas emissions (GHG) to prevent the worst effects of climate change. In 2018, the International Panel on Climate Change released a special report which updated the probable consequences of global warming and stated that future climate-related risks are greater if warming exceeds $1.5^{\circ} \mathrm{C}$ (Hoegh-Guldberg 2018). This report also included a chapter on mitigation pathways to achieve the goal of limiting warming to $1.5^{\circ} \mathrm{C}$. While it is acknowledged that renewable energy sources are crucial to reaching the $1.5^{\circ} \mathrm{C}$ target, the IPPC reported indicated that reducing demand in end use sectors would also be important in mitigation strategieswith buildings being a substantial energy consumer. Reductions in energy demand can lead to flexibility in choices available for emissions reduction strategies (Rogelj 2018). Buildings consume a large proportion of the energy required for human activity, and overall account for approximately $19 \%$ of the world's greenhouse gas emissions (Residential and Commercial Emissions in the United States 2017; Australian Energy Update 2020; Lucon 2014).

The urgent challenge of reducing energy associated with buildings to reduce carbon emissions includes policy, energy sources, operational energy efficiency, peak energy demand reduction and embodied energy. Studies more broadly on sustainable buildings include Zuo and Zhao (2014) and Hossaini et al. (2015). Net Zero Energy Buildings (NZEBsbuildings that generate sufficient renewable energy on site to meet their energy needs, with net zero greenhouse gas emissions) are an end objective for sustainable buildings. Hu and Qiu (2019) use building simulation methods to conclude that policy-based approaches could achieve net-zero buildings in three countries-China, the USA, and Germany-by 2050. Du et al. (2019) present a study indicating that adoption of prefabrication technologies contribute significant potential for reducing $\mathrm{CO} 2$ emissions over the life cycle of residential buildings.

This study focusses on the challenge of improving building operational energy efficiency.

In combination with this carbon reduction and energy efficiency imperative, modern occupant expectation of thermal comfort often requires energy-intensive heating ventilation and air conditioning (HVAC) systems. Widespread adoption of better building practices through design schemes such as Passive House (2020) as well as initiatives such as LEED (USGBC 2020), the Living Building Challenge (Living Building Challenge 2020) and Green Star in Australia (GBCA 2020) have all contributed to improvements in building energy efficiency. The widespread demand and adoption of these rating schemes signifies the demand for the development of initiatives that meet the energy reduction imperative while also maintaining comfort.

Improving thermal performance of building envelopes, including facades, is a key method to reduce building operational energy consumption while providing expected levels of occupant comfort. Historically, humanity has perceived building envelopes as static structures (Knaack et al. 2007). Only relatively recently -in the past half-century or sohave façade-integrated systems been recognised as important factors in reducing building operational energy consumption (Wigginton and Harris 2002), with examples of active and passive façade systems described in Schittich et al. (2006). Other studies to improve façade energy efficiency include: Lee et al. (2002), reviewing high-performance commercial building facades; Al-Hazmy (2006), analysing heat transport through hollow building blocks; Liu et al. (2015) reviewing control strategies for intelligent glazing systems; and He and Hoyano (2010) assessing a passive evaporative cooling wall. Elkhayat et al. (2020) conduct a life cycle assessment of three high-performance glazing systems, Kim and Olsen (2015) report on radiant systems, while Lydon et al. (2017) investigate multifunctional building elements. Porous ceramic materials were tested by He and Hoyano (2010), while novel 'breathing walls' have been proposed by (Craig and Grinham 2017). Examples of active, integrated unitised facades have been constructed, for example, in the Debitel 
Headquarters in Stuttgart, Germany (Knaack et al. 2007). Double skin facades have become widespread and tailored to different climates, for example, see Poirazis (2006), Haase (2008), and Hamza (2008). The Ogunmakinde et al. (2021) also note the need for construction materials to fit within a circular economy, such that raw inputs reuse and recycle materials from construction and other industries, and that construction materials can be recycled following dismantling of building assets. Researchers have investigated opportunities to use waste products from other industries, such as insulation from recycled textiles (Islam and Bhat 2019) and waste wool and polyester (Patnaik et al. 2015). Other potential opportunities to improve sustainability of insulation have been reviewed by Asdrubali et al. (2015), including natural and recycled materials. Geopolymer foam concrete, as reviewed by Zhang et al. (2014), also demonstrates opportunities for the integration of sustainable materials in the construction of building facades. Other reviews have focussed on recycled fibres in reinforced concrete (Merli et al. 2020), recycled plastic in concrete (Siddique et al. 2008) and crushed waste glass in construction (Mohajerani et al. 2017).

The increase in active façade installations in buildings is partly due to the developments in the manufacturing industries to support the development of sophisticated components that are required. The advances in electronics and information technology-so-called "Industry 3.0"-allowed the refinement of materials, processes, sensors and controls necessary for successful active façade systems. Currently, there is a shift to "Industry 4.0", originally advocated in Germany. Industry 4.0 advocates the establishment of internal and external cross-linking and digitalisation both within a product life cycle and across different product life cycles. Cross-linking is dependent upon high-quality data collection and analytics, but opens up opportunities for an integrated approach to value chain management and product life cycles, where materials inputs and end-of-life considerations are more readily considered through data sharing and analytics across information networks (Stock and Seliger 2016). A Sustainable Industry 4.0 Framework has been proposed by Kamble et al. (2018), consisting of Industry 4.0 Technologies, Process Integration and Sustainable Outcomes. Similar concepts are derived from the review conducted by Khan et al. (2021). The advantages of these approaches are further enhanced and embedded through "smart" manufacturing process that exploit deep learning based on data representation. This is equally reliant on data input and analysis (Wang et al. 2018).

Alongside developments in active façade technology and, through Industry 4.0, the production capability to fabricate such facades, biomimicry-innovation through natural inspiration-provides additional opportunities for innovation and improvements to building façade performance. The term itself is derived from Greek: 'bio' coming from the Greek 'bios' or life, while 'mimicry' is derived from 'mimesis' meaning imitation (Benyus 1997). By studying natural adaptions, from an ever-growing body of biological knowledge, innovators can extract functional characteristics and translate these characteristics into innovative, adaptive, flexible and more efficient designs. Life has been evolving on earth for over 3.8 billion years and has adapted to changing environmental circumstances (Gordon 1984). Life has, for example, derived high performance materials using common elements (Bhushan 2009). Benyus' contends that biomimicry for innovation follows three axioms "Nature as model", "Nature as measure" and "Nature as mentor" (1997). Pedesen Zari identifies two fundamental approaches in the built environment-defining a human need and investigating how this is achieved in nature, termed "design looking to biology" (2007) and translating a characteristic, species or ecosystem to a human design system- - biology influencing design" (2007). Biomimicry includes aspects of interpretation, adaptation or derivation from biology (Vincent et al. 2006). In modern technology, biomimicry has been shown to be a successful method to engender innovation (Benyus 1997). A systematic approach to biomimicry has been proposed to combine biomimicry with Teoriya Resheniya Izobretatelskikh Zadatch (TRIZ), interpreted as a "Theory of Inventive Problem Solving", which aims to use biomimicry to resolve design challenges and trade-offs (Vincent and Mann 2002). Furthermore, biomimicry has been noted as a pillar to the circular economy (Ogunmakinde et al. 2021).

In the built environment, biological inspiration has influenced architectural design throughout history (Aldersey-Williams 2003; Hersey 1999). However, application in the built environment has tended towards aesthetics and morphology or bio-utilisation (e.g. green walls and roofs). The application of biomimicry to building facades in particular, has been limited to date. Pawlyn (2011) examined biomimetic concepts across architectural disciplines. Gruber (2011) examines the relationships between biology and architecture and the approaches being used to apply biomimicry in architecture. Insect species behaviour (stigmergy) has been aligned with façade-integrated Peltier devices (BermejoBusto 2016). In terms of constructed projects exemplifying biomimetic skins, Singapore's Esplanade-Theatres on the Bay (DP Architects and Michael Wilford and Partners 2002) resembles the local tropical durian fruit, while the Kunsthaus Graz in Austria, by architects Peter Cook and Colin Fournier and consortium ARGE Kunsthaus, 2003, is an organic, biomorphic structure. The One Ocean pavilion in South Korea, by Soma architects in collaboration with Knippers Helbig Advanced Engineering, 2012, is one example where a specific, dynamic, functional characteristic, in this 
Fig. 1 L: Isometric of unitised façade system (Knaack et al. 2007); R: Debitel headquarters exemplifying unitised façade, Stuttgart (photo by author)

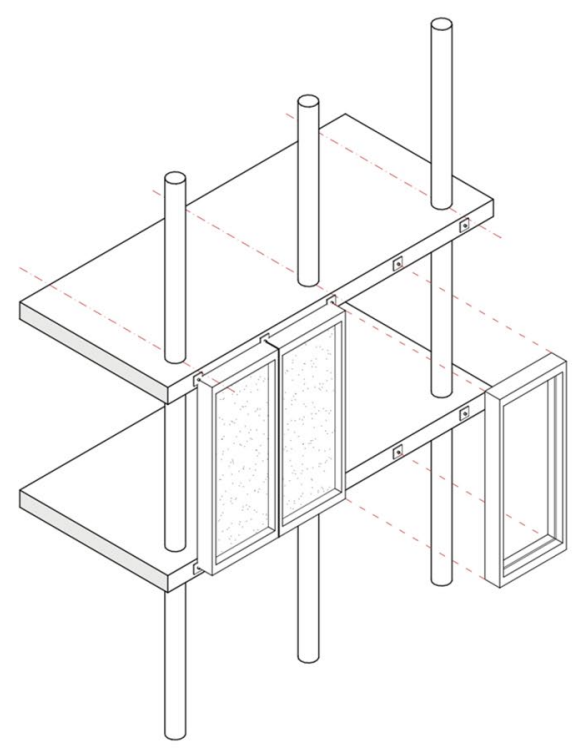

case a mechanism for motion, has been adapted from nature into an active building skin for a project that has reached construction stage.

Badarnah $(2012,2015)$ proposed a specific conceptual framework for incorporating biomimetic initiatives into building skins including energy and comfort, but also structure, water management, materials and waste. Badarnah (Badarnah 2017) has also presented morphology-based methods for biomimetic façade design. Other researchers to propose schemes for integrating biomimicry to improve the functional performance of building facades include: AlObaidi et al. (2017), with a systematic quantitative literature review, Gruber and Gosztonyi (2010), comparing biological skin mechanisms with architectural analogies, Schleicher et al. (2015), conceptualising bio-inspired flexible façade shading schemes, and López et al. (2017), presenting a methodology to collection plant adaptions and guide mapping to architectural designs.

Research by Webb et al. (2013, 2015, 2018); Webb et al. (2011) has shown that specific biomimetic strategies could improve the thermal performance of building envelopes. Testing of the efficacy of the biomimetic design was accomplished through digital modelling and building energy simulation. Others have used the simulation method for assessing building energy consumption. For example, Kumar et al. (2021) use energy simulation to energy performance of residential buildings applying new energy codes Kabul, while Heravi et al. (2020) use simulation as part of an optimisation study into nearly zero energy building's design in developing countries. The methodology in the current study translated biomimetic principles and processes into a heat analysis and energy simulation engine.

Previously, animal fur and blood perfusion were selected as template characteristics for a biomimetic façade design
(Webb 2018; Webb et al. 2018). Fur and perfusion were selected for the design based on their effectiveness as strategies evolved by homeothermic mammals to maintain steady core body temperatures in a wide range of environments (Schmidt-Nielsen 1997). Many mammals use a wide variety of hair and fur types to provide insulation, with heat transfer assessments on polar bears (Jessica et al. 2002), the rock squirrel (Walsberg 1988b), wet fur (modelled) (Gebremedhin and Wu 2001), the Harris antelope squirrel and roundtailed ground squirrel (Walsberg 1988a) and a comprehensive study by Liwanag (2008) on fur and blubber in marine mammals.

Digital simulations of biomimetic facades in a unitised façade system (refer Fig. 1 for façade type example) with animal fur and perfusion characteristics were constructed to test the hypothesis that these building envelope features would improve building energy efficiency while maintaining thermal comfort. Simulation results indicated that this façade, based on animal fur and blood perfusion, could be effective in reducing operational energy and peak heating and cooling loads by more than $50 \%$ in an office building in a temperate climate of Melbourne, Australia (Webb 2018; Webb et al. 2018). Other researchers have also proposed biomimetic features for building facades, such as Fecheyr-Lippens and Bhiwapurkar (2017) using building simulation to test a high-albedo façade with phase change materials for a small office building in Chicago, USA, with an estimated energy reduction of 68\%. Kuru et al. (2018) tested a geometric façade based on ribs and stomatal openings of the barrel cactus on a naturally-ventilated education building in Sydney, Australia, and found a potential improvement by $51.5 \%$ for the thermal comfort acceptability. Park (2016) introduced biomimetic strategies based on reflecting superposition eyes to improve functional 


\section{World map of Köppen-Geiger climate classification}
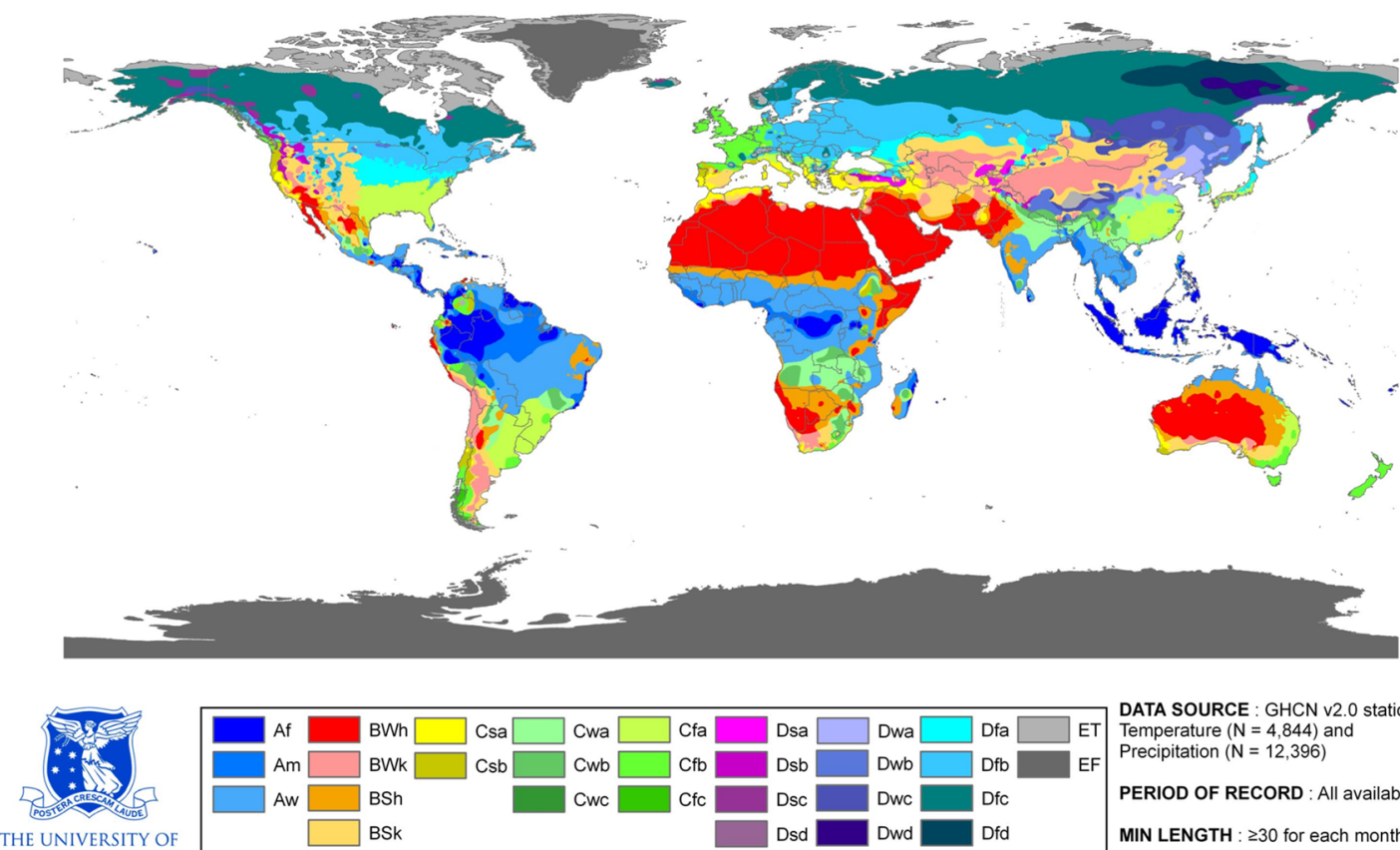

\begin{tabular}{|c|c|c|c|c|c|c|c|c|}
\hline Af & BWh & \multirow{4}{*}{$\begin{array}{l}\text { Csa } \\
\text { Csb }\end{array}$} & Cwa & Cfa & Dsa & Dwa & Dfa & ET \\
\hline Am & BWk & & Cwb & $\mathrm{Cfb}$ & Dsb & Dwb & Dfb & EF \\
\hline \multirow[t]{2}{*}{ Aw } & BSh & & Cwc & Cfc & Dsc & Dwc & Dfc & \\
\hline & BSk & & & & Dsd & Dwd & Dfd & \\
\hline
\end{tabular}

DATA SOURCE : GHCN v2.0 station data Temperature $(\mathrm{N}=4,844)$ and Precipitation $(N=12,396)$

Fig. 2 Köppen-Geiger climate map of the world (Peel et al. 2007)

illuminance in sports stadiums in Incheon, Korea. Craig et al. (2008) proposed a cellular structure with thermal mass as a roof cooling mechanism in Riyadh, Saudi Arabia, using TRNSYS to demonstrate a $4.5^{\circ} \mathrm{C}$ reduction in roof temperature.

However, testing of the fur and perfusion façade, and these other case studies, have been limited to a singular test case for one building typology in individual climate zones. Research has been limited on wider application of biomimetic façade initiatives for building facades. For more widespread application, it was important to test the efficacy of biomimetic façade designs in different building types and in different climate zones. The hypothesis in this study was to assess whether biomimetic building facades, based on their energy-reduction potential, have a broader application. A case study was proposed to test whether a biomimetic building façade, based on animal fur and blood perfusion, would be as effective at improving energy efficiency in different climate zones and on different building types as it was shown for one building typology (office) in a temperate climate. The confirmation or rejection of this hypothesis would indicate whether biomimetic facades could be successful in broader applications, rather than individual projects. The study also aims to demonstrate suitable methods for assessing biomimetic initiatives through mathematical modelling and building simulation.

\section{Materials and methods}

As indicated in Sect. 1, the objective of this expanded study was to determine whether the animal fur-perfusion façade design was at least as effective in a broader range of climate zones and building types as it was shown for an office building in a temperate climate.

A conventional method to distinguish climate zones is the Köppen-Geiger $(\mathrm{K}-\mathrm{G})$ climate classification, refer Fig. 2 (Peel et al. 2007). This study would test the animal fur-perfusion façade in four very different climate zones:

- Temperate oceanic (Cfb)

- Hot desert (Bwh)

- Tropical savannah (Aw)

- Humid continental (Dfb)

Furthermore, the study examined the effectiveness of the fur and perfusion biomimetic building facade in a set of three different operational applications:

- Office buildings,

- School buildings, and

- Aged care facilities. 
The method for the assessment of the fur and perfusion biomimetic façade for different climate zones and building types could be summarised as follows, with section references for descriptions of detailed methods, inputs and assumptions:

\section{- Section 2, Materials and Methods}

- Section 2.1, Façade Model Development. Using the methods developed previously (Webb 2018; Webb et al. 2018), heat and energy transfer models were created to represent building facades.

- A model was constructed for a conventional static façade composed of lightweight construction materials (reference façade) to act as a baseline for comparison to the biomimetic designs in terms of heat transfer and annual energy performance.

- Biomimetic façade models were constructed. The equations for an external fur layer and a perfusion layer within the façade were included to represent the insulation influence of the fur and fluid heat transfer effects (refer Sect. 3). ${ }^{1}$

- Section 2.2, Dynamic Building Simulations. Reference and biomimetic façade models were integrated into to a conventional Building Energy Simulation (BES) software package to test the performance of the proposed biomimetic façade designs.

- Section 3, Results and discussion

- Section 3.1-Extent of simulations, where the format of the simulations was described.

- Section 3.2-Results for the façade scenarios in the selected climate zones were summarised and discussed.

- Section 3.3-Results for the façade scenarios for the three selected building types were summarised and discussed.

- Section 3.4-Comparison with simulation and Energy Reduction Studies. The results obtained in the current study were compared with a selection of alternative energy efficiency measures for different climate zones building types.

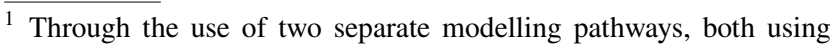
physically valid methods of solution, the biomimetic façade models were previously verified as accurate and consistent with physically viable results (Webb 2018).
}

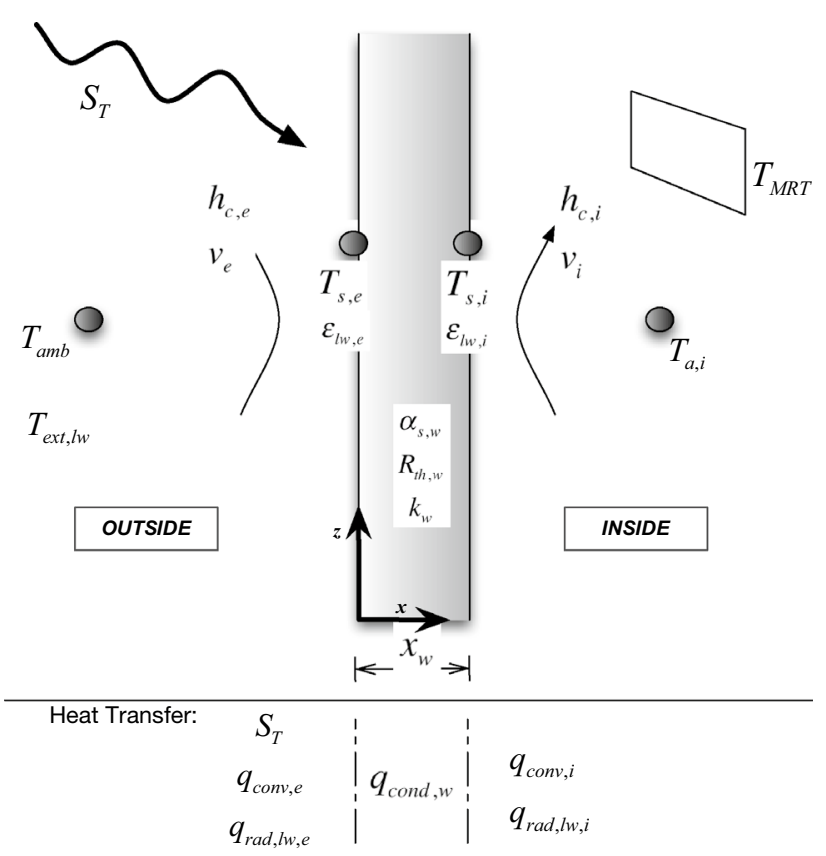

Fig. 3 Representation of planar façade

- Section 4, Limitations and further work

- The limitations in the methods used in this study were identified and examined.

- Economic impact was discussed.

- Section 5, Conclusions

- The conclusions for the study were drawn, including whether the results confirmed the hypothesis described in Sect. 1.

\section{Façade model development}

The façade models for conventional materials and the biomimetic fur and perfusion facades are summarised below. For full model development, refer to Webb (2018) and (Webb et al. 2018).

\section{Reference}

For the Reference Façade (Ref), a time-dependent model was developed based on the generalised 1-D heat equation through a plane wall without sources or sinks (Holman 2001). The temperature, $T(x, t)$, was calculated as:

$$
\frac{\partial^{2} T}{\partial x^{2}}=\frac{1}{\alpha_{w}} \frac{\partial T}{\partial T}
$$

The physical situation is represented in Fig. 3. A heat balance at the inside and outside surfaces was conducted to define the internal and external boundary conditions. 
For the external surface:

$S_{T}+q_{\text {rad,lw,e }}=q_{\text {conv }, e}+q_{c o n d, w, e}$

These heat balance boundary conditions were expanded to include relevant coefficients and temperatures:

$$
\begin{aligned}
-k_{w} & \left.\frac{\partial T}{\partial x}\right|_{x=0}=q_{c o n d, w, e} \\
= & \alpha_{s, w} S_{T}+\left(h_{c, e}+h_{r a d, l w, e x t}\right)\left(T_{a}-T_{s, e}\right) \\
& +h_{r a d, l w, g}\left(T_{g}-T_{a}\right)+h_{r a d, l w, s k y}\left(T_{s k y}-T_{a}\right)
\end{aligned}
$$

Radiant heat transfer coefficients were linearized, e.g. for long wave radiation:

$h_{r a d, l w, e}=\frac{\varepsilon_{r a d, l w} \sigma\left(T_{a}^{4}-T_{s, e}^{4}\right)}{T_{a}-T_{s, e}}$

A similar heat balance was conducted for the inside surface:

$q_{\text {cond }, w}=q_{\text {conv }, i}+q_{\text {rad,lw,i }}$

\section{External fur layer}

Multiple models and methods have been devised to calculate heat transfer through fur or, equivalently (refer Webb (2018); Webb et al. (2011)). The Davis and Birkebak (1974) model was selected for translation to a fur-lined biomimetic façade design. This model related conductive energy flux across the fur layer, $q_{\mathrm{f}}$, to a temperature gradient, $\Delta T$, and fur thickness layer, $L_{\mathrm{f}}$, via an effective fur thermal conductivity, $k_{\mathrm{eff}}$, as follows:

$q_{f}=k_{\text {eff }} \frac{\Delta T}{L_{f}}$

Further development on the radiation heat transfer using an extinction coefficient and energy relationships let to the following expression:

$q_{f}=\frac{k_{e f f}}{L_{f}}\left(T_{s, e}-T_{f, e}\right)+\left(1-\frac{\cos \theta_{S}}{N_{f, S} F_{S}}\right) q_{S, s k i n}-\frac{\alpha_{f, S} S_{T} \cos ^{2} \theta_{S}}{N_{f, S} F_{S}}$

where: $\alpha_{\mathrm{f}, \mathrm{S}}=$ bulk fur solar absorptivity, $q_{\mathrm{S} \text {,skin }}=$ solar radiation absorbed by skin, $F_{\mathrm{S}}=$ absorption factor at solar wavelengths, $N_{\mathrm{f}, \mathrm{s}}=$ optical thickness for solar wavelengths (Webb et al. 2018), $\beta_{\mathrm{h}, \mathrm{S}}=$ hair extinction coefficient across solar wavelengths (Davis and Birkebak 1974).

With an expression for heat transfer through the fur layer, $q_{\mathrm{f}}$, the fur heat transfer was integrated into the façade model (Fig. 4). Heat transfer through the fur was

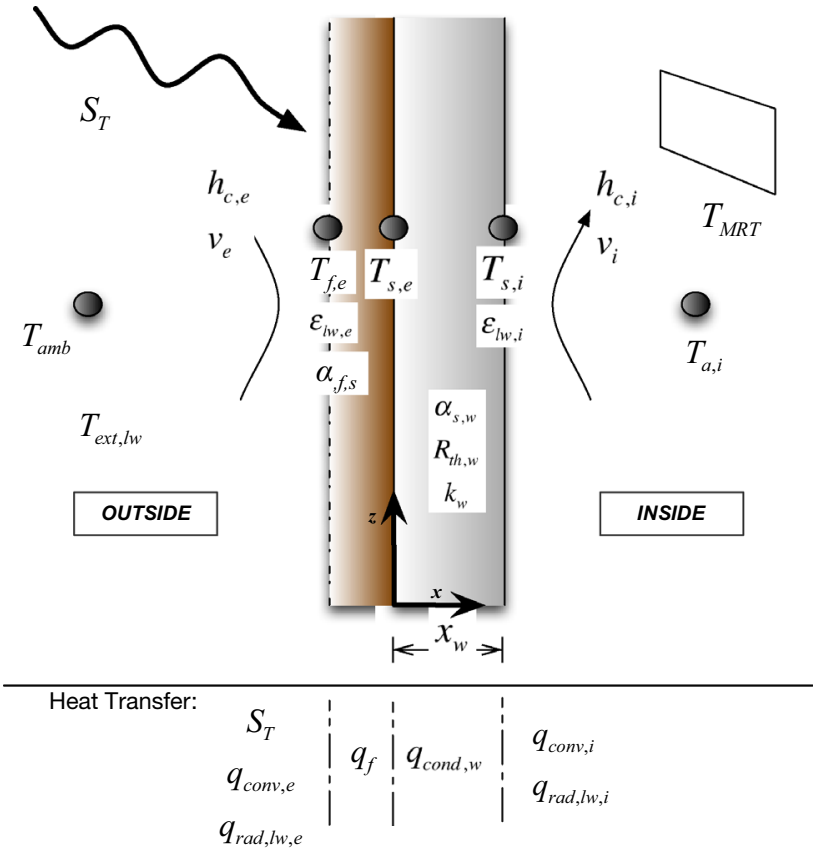

Fig. 4 Façade model with external fur lining

then incorporated into a heat balance on the external surface of the wall:

$S_{T}+q_{\text {rad }, l w, e}=q_{c o n v, e}+q_{c o n d, w, e}$

Following the solar heat transfer model developed for the reference, this became (refer Fig. 3):

$$
\begin{aligned}
q_{f}= & \alpha_{s, w} S_{T}+\left(h_{c, e}+h_{\text {rad }, l w, e x t}\right)\left(T_{a}-T_{s, e}\right) \\
& +h_{r a d, l w, g}\left(T_{g}-T_{a}\right)+h_{r a d, l w, s k y} T_{s k y}-T_{a}
\end{aligned}
$$

\section{Perfusion layer}

Pennes (1948) provided a fundamental basis for the study of heat transfer in living tissue, which was selected as the basis to describe fluid perfusion in the biomimetic façade model as follows (refer Fig. 5 and Webb et al. (2018)):

$k_{t} \frac{\partial^{2} T}{\partial x^{2}}+\rho_{b} c_{p, b} \dot{w}_{b}\left(T_{a o}-T\right)=\rho_{t} c_{p, t} \frac{\partial T}{\partial t}$

Equation (10) could be solved in place of the unmodified heat equation (Eq. (1)) as the basis for perfusion in the biomimetic façade design. 


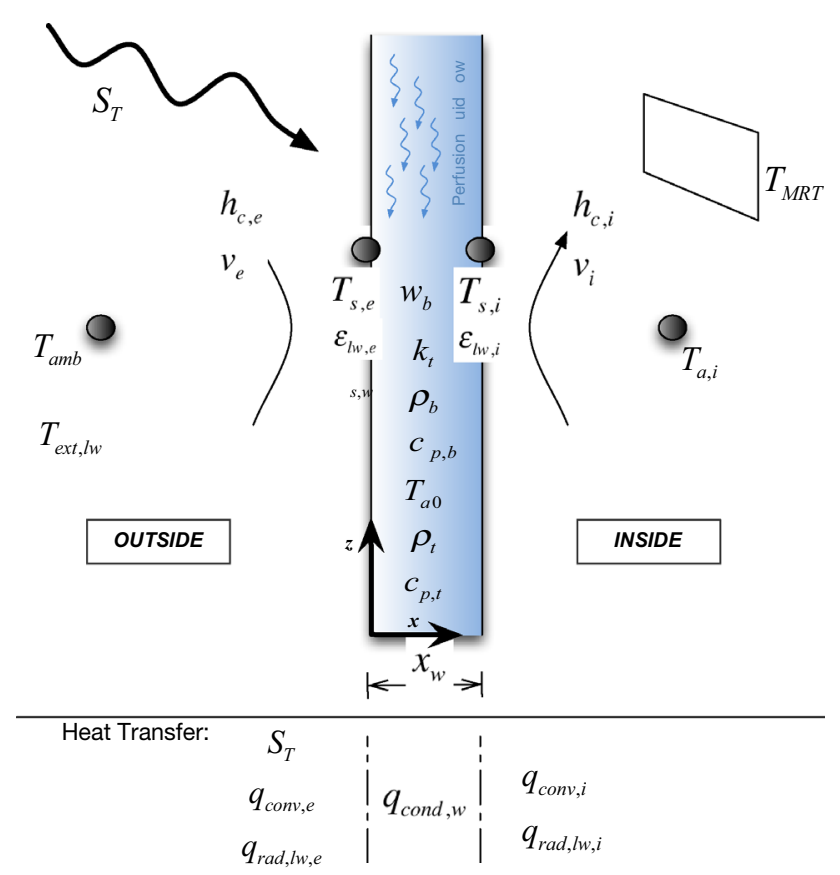

Fig. 5 Façade model with internal perfusion

\section{Finite difference solutions}

The equations in the preceding sections required suitable solution methods for adoption in a dynamic building annual energy simulation. This led to the introduction of a finite difference scheme to numerically solve the model equations (Webb 2018; Webb et al. 2018). An explicit finite difference scheme was developed for the biomimetic façade, with the nominal 0.1-m-thick façade split into four discrete steps. Accordingly, the fundamental heat equation, Eq. (1), became:

$T_{i}^{n+1}=F o\left[T_{i-1}^{n}-\left(2-\frac{1}{F_{0}}\right) T_{i}^{n}+T_{i+1}^{n}\right]$

Here, $T_{\mathrm{i}}$ represented the temperature for the $i t h$ internal node at timestep $n+1$ and the Fourier number, Fo, is:

$F o=\frac{\alpha_{w} \Delta t}{\Delta x^{2}}$

The finite difference models for the reference and biomimetic facades are shown in Fig. 6.

\section{Dynamic Building simulations}

Customised finite difference models were developed in the preceding section, representing the characteristics of both conventional and biomimetic façades. These numerical models were implemented in TRNSYS for annual dynamic energy simulation. The biomimetic design model adapted for TRNSYS software in this study was a façade that included both fur and perfusion initiatives, i.e. it included the advantages of both. TRNSYS (TRaNsient SYstem

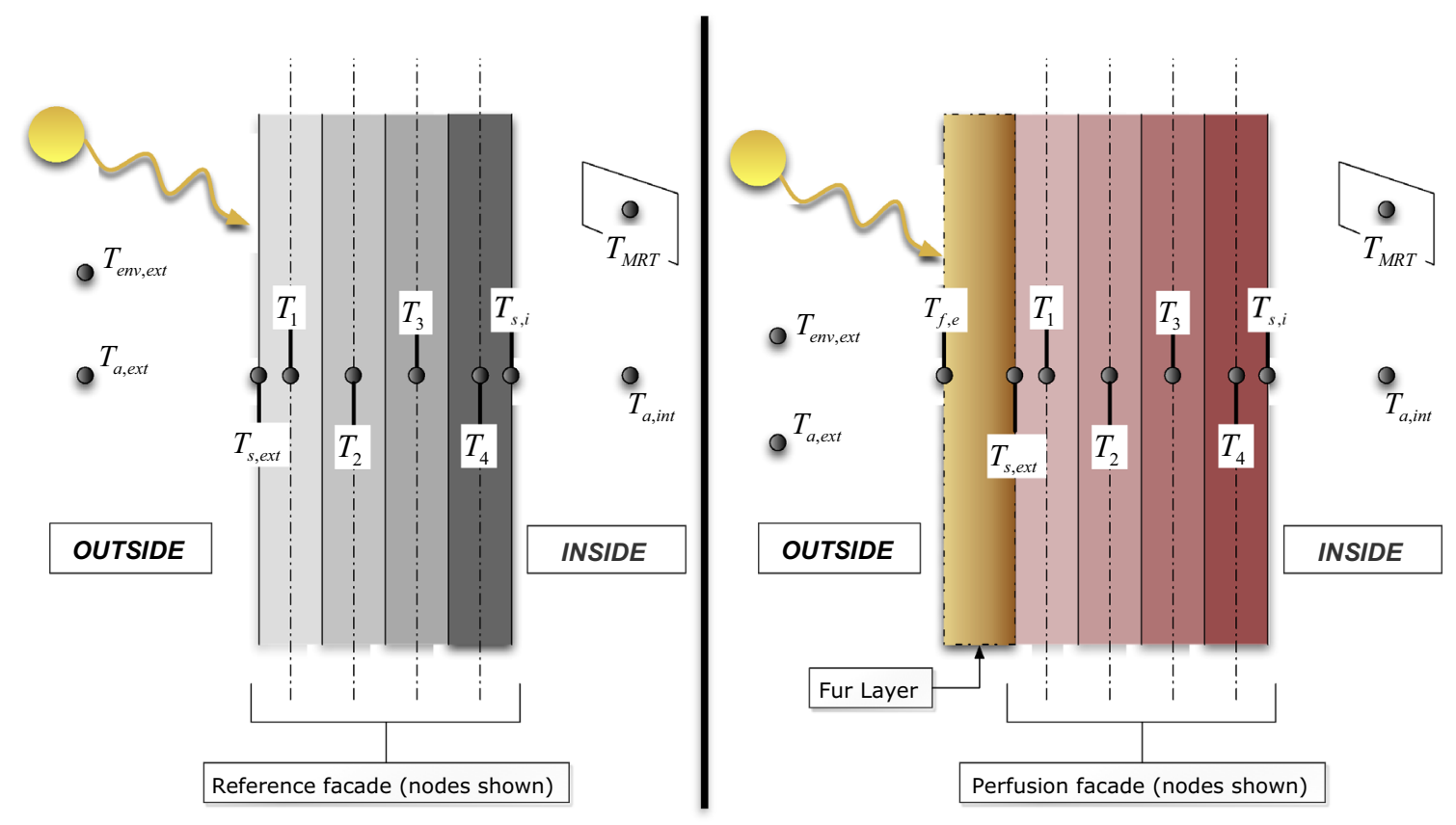

Fig. 6 Finite difference façade models: reference (L) and biomimetic (R) 
Fig. 7 Type 56 office model: floor plan and separate thermal HVAC zones
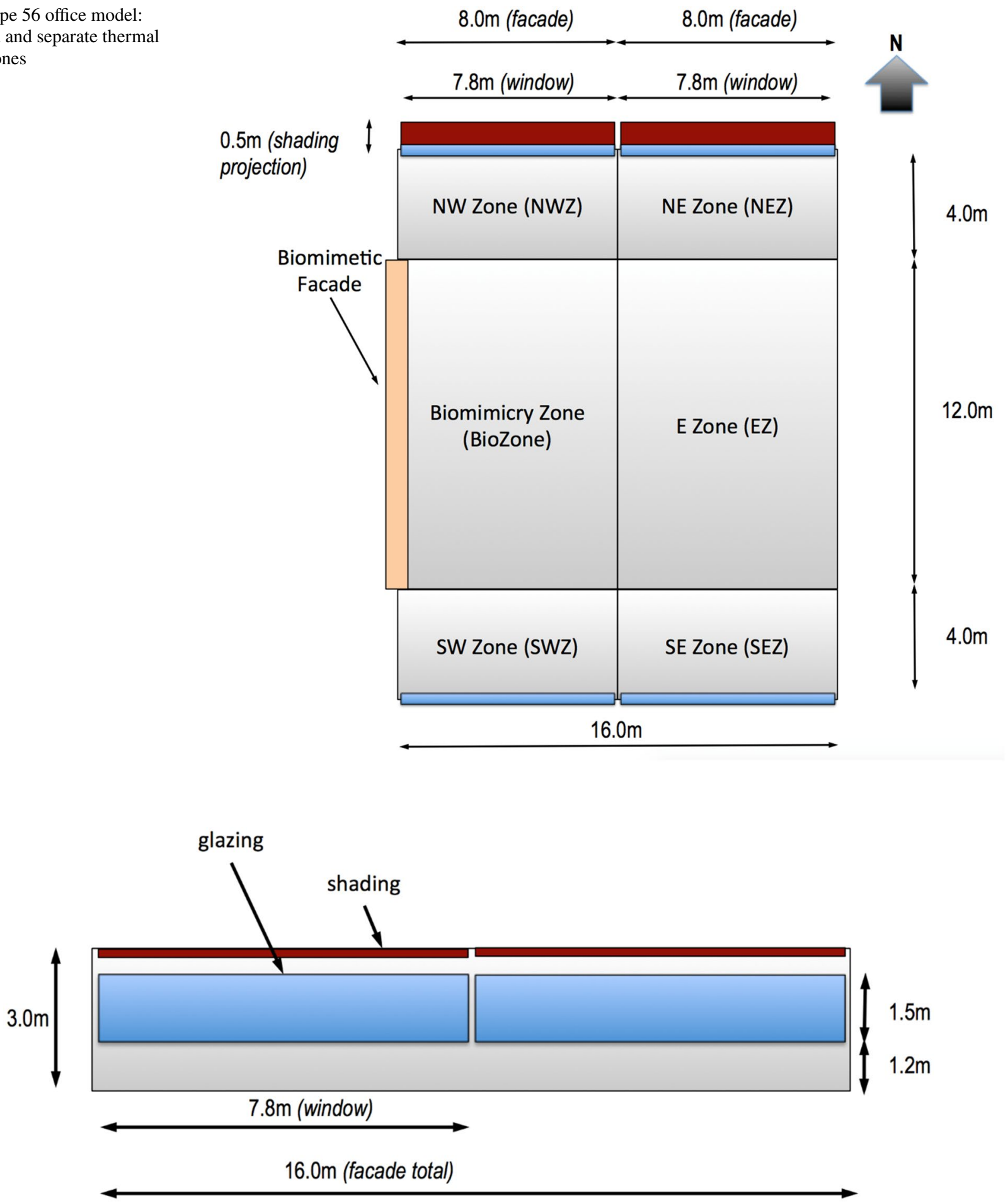

Fig. 8 Type 56 office model: north elevation

Simulation or TRNSYS) is a well-recognised method for testing building designs (refer validation standard and (ASHRAE 140-2017) and Neymark and Judkoff (2008)).

\section{Building Simulation model}

In all climates selected, a rectangular floor plate was created, containing six zones, with glazing north and south facades (Figs. 7 and 8). The model assumed that the 
Table 1 TRNSYS model building fabric

\begin{tabular}{|c|c|c|c|}
\hline Element & Description & Thickness (m) & $\begin{array}{l}\text { Thermal resist- } \\
\text { ance }\left(\mathrm{m}^{2} \mathrm{~K} \mathrm{~W}^{-1}\right)\end{array}$ \\
\hline Walls & Lightweight metallic façade with EPS insulation & 0.104 & 2.93 \\
\hline Floor & Concrete slab with air gap and ceiling tile below & 0.228 & 1.15 \\
\hline Roof & $\begin{array}{l}\text { Metal deck with glass wool batt insulation and ceiling plenum } \\
\text { above acoustic tile }\end{array}$ & 0.134 & 5.43 \\
\hline \multirow{2}{*}{$\begin{array}{l}\text { Internal partitions (between } \\
\text { zones) }\end{array}$} & Gypsum plaster stud walls (no insulation) & 0.090 & 0.48 \\
\hline & & SHGC (-) & $\begin{array}{l}\text { Thermal trans- } \\
\text { mittance }(\mathrm{W} \\
\left.\mathrm{m}^{-2} \mathrm{~K}^{-1}\right)\end{array}$ \\
\hline Glazing & $\begin{array}{l}\text { Double: } 8.38 \mathrm{~mm} \text { Neutral Comfortplus- } 12 \mathrm{~mm} \text { air- } 6 \mathrm{~mm} \\
\text { EnergyTech Clear }\end{array}$ & 0.400 & 1.70 \\
\hline Frame ( $10 \%$ of window area) & Standard aluminium & 0.450 & 12.50 \\
\hline
\end{tabular}

$*$ SHGC $=$ Solar heat gain coefficient

building floor was situated above another floor of identical dimensions (creating an adiabatic floor surface), while the ceiling was externally exposed above via an external roof construction.

\section{Building fabric}

Building fabric and glazing for the Type 56 model are shown in Table 1.

\section{HVAC system}

The occupied zones on the modelled building floor were assumed to be air conditioned to meet thermal comfort requirements of occupants during hours of operation, which depended upon the building type, as per Table 2. The occupancies for each building type were based on standard assumptions regarding occupancy of the three classes of building. It is acknowledged that the Covid 19 Pandemic may lead to long term changes in office building occupancy. However, the schedules used in the modelling remain the standard profiles in assessing building energy consumption and form the main tool for comparison of energy-saving designs for buildings.

HVAC system design calculations were based on an assumption that the building would be serviced by a chilled water (CHW) and heating hot water (HHW) variable air volume (VAV) air conditioning system for both heating and cooling. Air would be cooled or heated via chilled or heating hot water. The following major components were required:

- Chiller (assumed air-cooled, Integrated Part Load Value of 3.7),
- Boiler (assumed gas-fired, efficiency 80\%),

- Fans,

- Chilled water pumps,

- Hot water pumps for heating.

- Outside at $11 \mathrm{~L} \mathrm{~s}^{-1}$ per person (Schittich et al. 2006).

The development of the specific pressures and capacities of HVAC equipment was as per Webb (2018). These were based, where possible, on minimum energy efficiency standards (National Construction Code BCA 2016 Volume $12016)$.

\section{Internal loads and schedules}

Three customary internal heat gains were added to the model: occupants, lighting, and electrical equipment (computers, printers, monitors, refrigerators, etc.). Lighting was specified as per the maximum lighting efficiency

Table 2 HVAC Schedule for each building class

\begin{tabular}{lll}
\hline Building class & HVAC daily operation \\
Office & $08: 00-18: 00$ \\
Aged care & $000-24: 00(24 \mathrm{~h})$
\end{tabular}


Table 3 Internal loads for building classes

\begin{tabular}{|c|c|c|c|c|}
\hline Building class & Occupants & $\begin{array}{l}\text { Lighting (W } \\
\mathrm{m}^{-2} \text { ) }\end{array}$ & $\begin{array}{l}\text { Equipment (W } \\
\mathrm{m}^{-2} \text { ) }\end{array}$ & $\begin{array}{l}\text { Activ- } \\
\text { ity level } \\
\text { (met) }\end{array}$ \\
\hline Office & 1 per $10 \mathrm{~m}^{2}$ & 9 & 11 & 1.2 \\
\hline Aged care & 1 per $20 \mathrm{~m}^{2}$ & 7 & 5 & 0.8 \\
\hline School & 1 per $2 \mathrm{~m}^{2}$ & 8 & 5 & 1.2 \\
\hline
\end{tabular}

Table 4 Performance measures for detailed analysis

\begin{tabular}{ll}
\hline Primary performance measures & Units \\
\hline Biomimetic zone annual HVAC energy consumption & $\mathrm{kWh}$ \\
Peak façade heat loss or gain & $\mathrm{W}$ \\
\hline
\end{tabular}

allowance given in the National Construction Code BCA 2016 Volume 1 2016). For offices, equipment heat gains were set to the specifications of NABERS Ratings for offices (Handbook for estimating NABERS Ratings 2019). For aged care, internal heat gains were set on the assumption that aged care facilities would have minimal equipment and account for items such as a computer terminal and TV, while school classrooms were also assumed to have minimal equipment loads (it was assumed that each student did not use a laptop).

Metabolic and clothing values were referenced from the data in the ASHRAE Handbook - Fundamentals 2009). A lower value of activity was ascribed to occupants in Aged Care buildings. Clothing was maintained consistently across all three cases and set at 0.6 clo (summer) and 0.95 clo (winter). The following Table 3 summarises these inputs.

\section{Performance metrics}

Building facades perform numerous functions; however, the primary measures for evaluating the effectiveness of the biomimetic facades in this study were the minimisation of building HVAC energy consumption and minimisation of peak façade heat loss and gain, as shown in the Table 4.

In addition to these energy-based criteria, it was also necessary to define 'thermal comfort' in measurable terms (Schittich et al. 2006):

- Indoor Air Temperature (IAT) - 20-25 ${ }^{\circ} \mathrm{C}$, and

- Mean Surface Temperature (MST)—no more than $3{ }^{\circ} \mathrm{C}$ different to air temperature.

\section{Results and discussion}

Using models for conventional and biomimetic facades described, integrated into a building model in TRNSYS (Sect. 2), annual simulations for the different climate zones and building typologies were conducted. The results for these simulations in terms of annual operational services energy and peak loads are presented herein.

Table 5 Climate simulations

\begin{tabular}{|c|c|c|c|c|}
\hline \multirow{2}{*}{$\begin{array}{l}\text { K-G climate } \\
\text { classification }\end{array}$} & \multirow{2}{*}{$\begin{array}{l}\text { Climate classification } \\
\text { description }\end{array}$} & \multirow[t]{2}{*}{ Example location } & \multicolumn{2}{|l|}{ Simulations } \\
\hline & & & Biomimetic (Biom) & Reference (Ref) \\
\hline $\mathrm{Cfb}$ & Temperate oceanic & Melbourne, Australia & Cfb Biom & Cfb Ref \\
\hline Dfc & Hot desert & Bechar, Algeria & Dfc Biom & Dfc Ref \\
\hline Bwh & Tropical savannah & Manilla, Philippines & Bwh Biom & Bwh Ref \\
\hline Aw & Humid continental & Stockholm, Sweden & Aw Biom & Aw Ref \\
\hline
\end{tabular}


Table 6 Building type simulations

\begin{tabular}{|c|c|c|c|c|c|}
\hline \multicolumn{2}{|c|}{ Building type } & \multirow[t]{2}{*}{ Example location } & \multirow[t]{2}{*}{ Climate description } & \multicolumn{2}{|l|}{ Simulations } \\
\hline Name & Abbreviation & & & Biomimetic (Biom) & Reference (Ref) \\
\hline Office & Ofc & Melbourne, Australia & Temperate & Ofc Biom & Ofc Ref \\
\hline Education & Edu & Melbourne, Australia & Temperate & Edu Biom & Edu Ref \\
\hline Aged Care & $\mathrm{AgdCr}$ & Melbourne, Australia & Temperate & AgdCr Biom & AgdCr Ref \\
\hline
\end{tabular}

Fig. 9 Annual energy for different climates-comparison

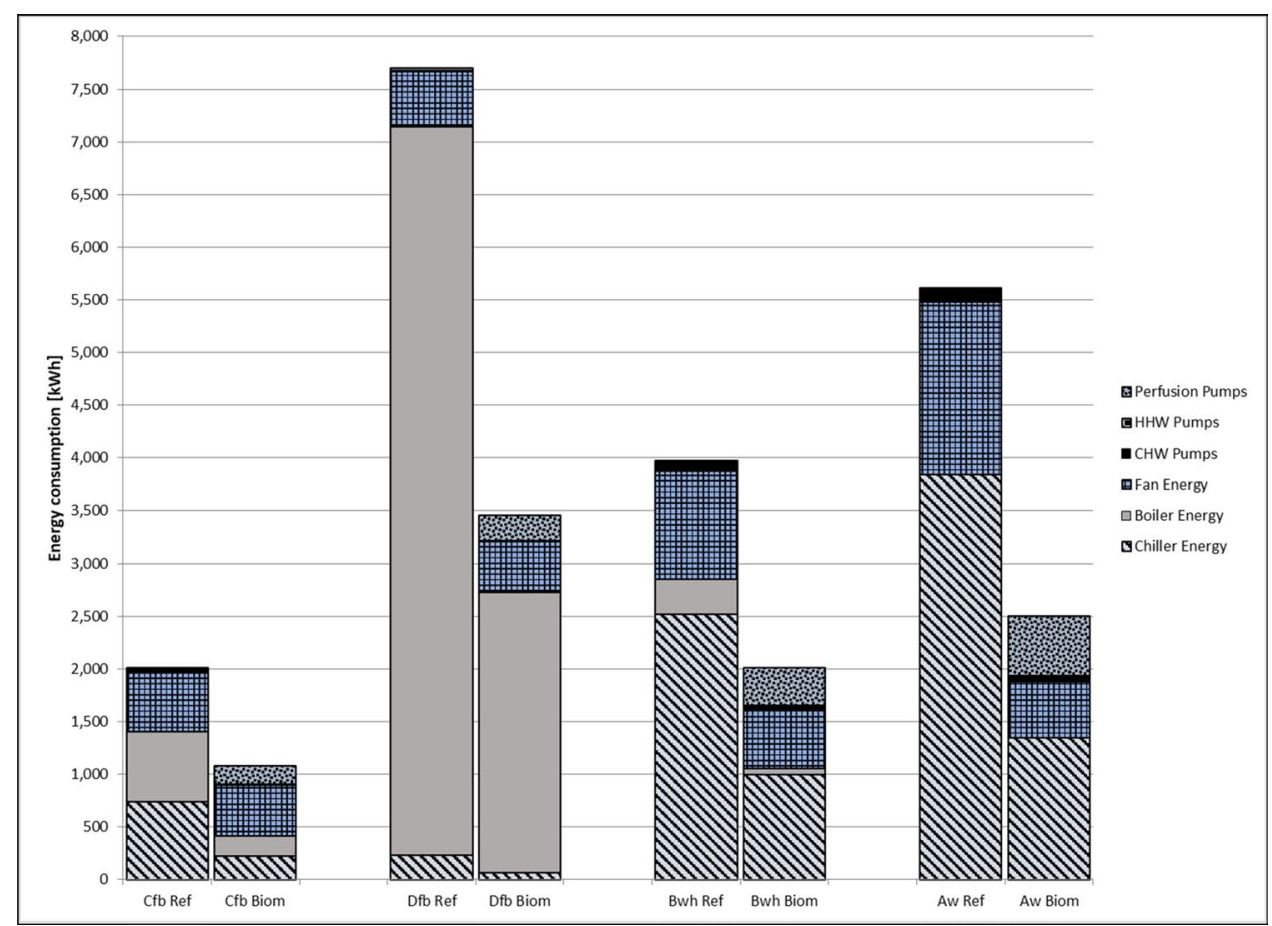

\section{Extent of simulations}

For each of the four climate zones, an annual dynamic energy simulation was conducted for both the biomimetic façade ('Biom') and the reference façade ('Ref') as indicated in the following Table 5 .

For each of the three building types, an annual dynamic energy simulation was conducted for both the biomimetic façade ('biom') and the reference façade ('ref') as indicated in the following Table 6 .

\section{Climate zones}

\section{Annual energy comparison: climate zones}

The following charts display annual energy results for the four climate zones for the biomimetic zone only (refer to Fig. 7). This allowed the analysis to focus on the performance of biomimetic facade and to reduce complexity in the presentation of the results. Figure 9 displays results of annual services energy consumption for each of the climate simulations with the biomimetic façade, including reference cases. Table 7 provides a summary of all the results across the different climate zones while Table 8 indicates the reduction that each biomimetic design achieved.

Figure 9 shows that the temperate oceanic climate zone (Cfb) - the baseline case-required least energy overall to maintain comfort conditions for occupants. As expected, more extreme climate cases required additional energy to maintain the comfort band of $20-25{ }^{\circ} \mathrm{C}$. Stockholm (Dfb), at a latitude of $56.3^{\circ} \mathrm{N}$ latitude, consumed the most energy, largely due to a significant proportion of heating and very limited cooling. Contrastingly, Béchar $\left(\mathrm{Bwh}, 31.6^{\circ} \mathrm{N}\right)$ and Manila (Aw, $14.6^{\circ} \mathrm{N}$ ), much closer to the equator, consumed more energy that the baseline $\mathrm{Cfb}$ case, due primarily to an increase in cooling requirements. The cooling demand (as indicated by the chiller energy) was six times greater than the baseline $\mathrm{Cfb}$ case. It was observed that the greatest cooling demand occurred in the Manila simulation (Aw), which also demanded additional cooling from the perfusion pumps.

Reviewing the comparative results, biomimetic cases outperformed the reference cases in all climate zones. Physical 
Table 7 Energy consumption for climate zones

\begin{tabular}{|c|c|c|c|c|c|c|c|c|}
\hline \multirow[t]{2}{*}{ Energy category } & \multicolumn{2}{|c|}{ Temperate oceanic } & \multicolumn{2}{|c|}{ Humid continental } & \multicolumn{2}{|c|}{ Hot desert } & \multicolumn{2}{|c|}{$\begin{array}{l}\text { Tropical } \\
\text { savannah }\end{array}$} \\
\hline & $\begin{array}{l}\text { Cfb } \\
\text { Ref }\end{array}$ & Cfb Biom & $\begin{array}{l}\text { Dfb } \\
\text { Ref }\end{array}$ & Dfb Biom & $\begin{array}{l}\text { Bwh } \\
\text { Ref }\end{array}$ & Bwh Biom & $\begin{array}{l}\text { Aw } \\
\text { Ref }\end{array}$ & $\begin{array}{l}\text { Aw } \\
\text { Biom }\end{array}$ \\
\hline Chiller energy & 741 & 222 & 228 & 61 & 2514 & 998 & 3841 & 1349 \\
\hline Boiler energy & 665 & 188 & 6914 & 2668 & 339 & 60 & 0 & 0 \\
\hline Fan energy & 571 & 487 & 527 & 482 & 1019 & 548 & 1637 & 527 \\
\hline CHW pumps & 30 & 10 & 9 & 2 & 92 & 44 & 136 & 61 \\
\hline HHW pumps & 2 & 1 & 20 & 8 & 1 & 0 & 0 & 0 \\
\hline Perfusion pumps & 0 & 173 & 0 & 237 & 0 & 358 & 0 & 566 \\
\hline Total & 2008 & 1080 & 7698 & 3457 & 3965 & 2008 & 5615 & 2503 \\
\hline
\end{tabular}

\begin{tabular}{lllll}
\hline Energy category & $\begin{array}{l}\text { Temperate oceanic } \\
(\text { Cfb Biom) }(\%)\end{array}$ & $\begin{array}{l}\text { Humid continental } \\
(\text { Dfb Biom) }(\%)\end{array}$ & $\begin{array}{l}\text { Hot desert (Bwh } \\
\text { Biom) }(\%)\end{array}$ & $\begin{array}{l}\text { Tropical savan- } \\
\text { nah (Aw Biom) } \\
(\%)\end{array}$ \\
\hline Chiller energy & -70 & -73 & -60 & -65 \\
Boiler energy & -72 & -61 & -82 & na \\
Fan energy & -15 & -9 & -46 & -68 \\
CHW pumps & -68 & -74 & -53 & -55 \\
HHW pumps & -72 & -61 & -82 & na \\
Perfusion pumps & na & na & na & na \\
Total & -46.2 & -55.1 & -49.4 & -55.4 \\
\hline
\end{tabular}

Table 8 Biomimetic design reductions in energy in each climate zone the Aw case was substantially higher than in the other climates (both biomimetic and reference simulations). This was likely due to the high, and almost continuous cooling demand requirements in a topical climate. The added insulation provided by the fur-lined façade provided a barrier to the external weather, but with small diurnal fluctuations and constant infiltration, the extra insulative effect was diminished, especially without the opportunity to obtain free cooling from cooler outside air temperatures during some parts of the day. This result pointed towards a more general trend indicating that additional energy-saving initiatives, other than improvements in the building envelope, must be considered to minimise overall building services energy consumption.

In this study, it was assumed that the energy source for heating was natural gas-fired boilers. However, given the accelerating impacts from climate change and the improvements in the technology, electric heat pumps have become more favourable as a heating source. Electric heat pumps have a COP range from 3.2 to 4.5 . Therefore, an alternative scenario was tested where the heat source was assumed to be an electric heat pump with a COP of 3.2. In this instance the corresponding energy results appeared markedly different, as shown in Fig. 10. Under these conditions, the only remaining climate with a proportionally significant heating consumption was the Dfb (humid continental) case. The 
Fig. 10 Annual energy for different climates-heat pump

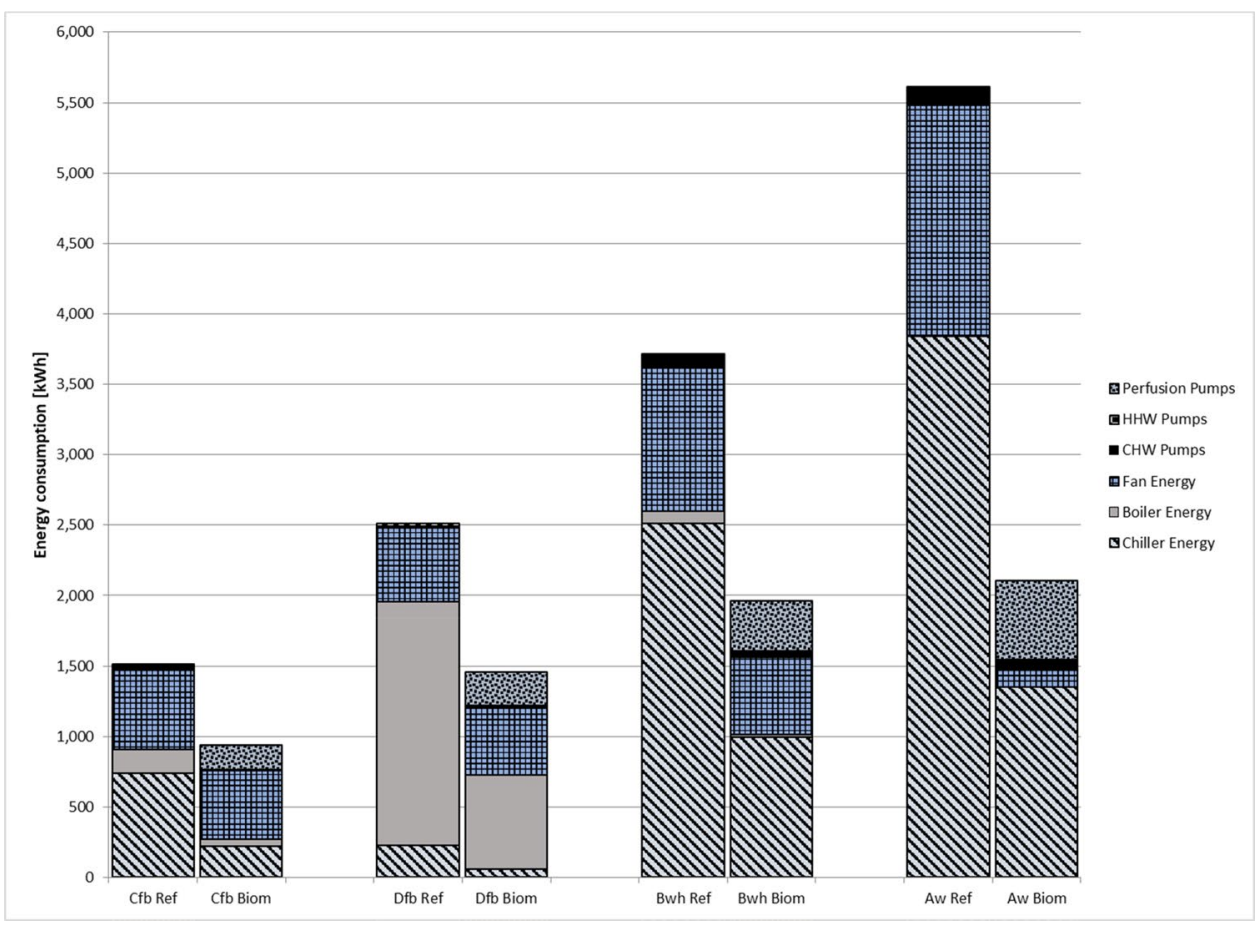

Fig. 11 Peak heating and cooling for different climates-comparison

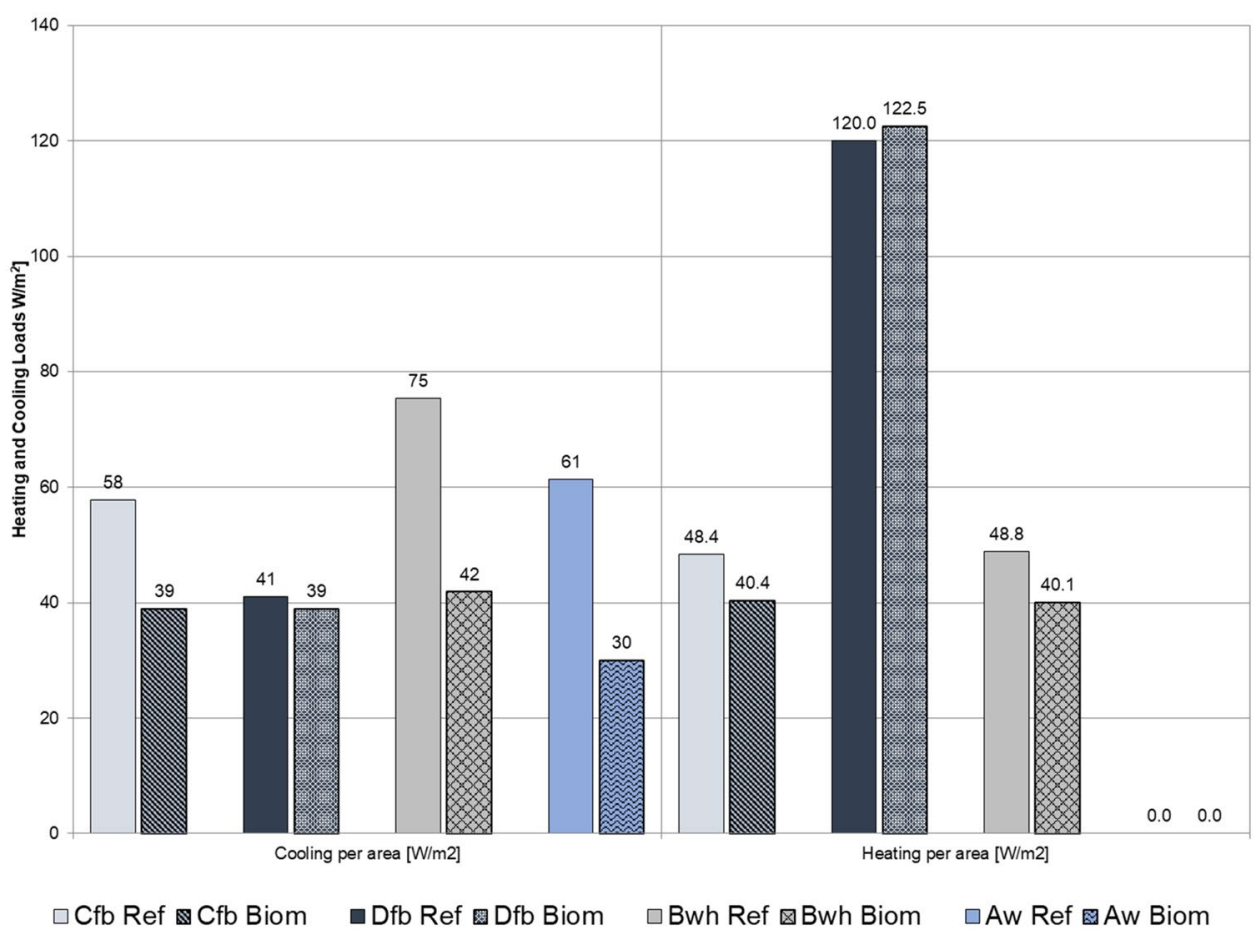

tropical Aw location now consumed the greatest annual building services energy, with a large margin between the reference Aw (tropical) case and the Bwh (hot desert) case (34\% difference). The difference in the biomimetic cases was not as pronounced (22\% difference). Even considering these variations from the gas-fuelled heating, it was clear that the biomimetic designs provided a substantial improvement in energy efficiency.

\section{Peak heating and cooling comparison: climate zones}

Peak heating and cooling results were compiled for the biomimetic zone. These loads represented the maximum annual 
Fig. 12 Annual energy for different building types-comparison

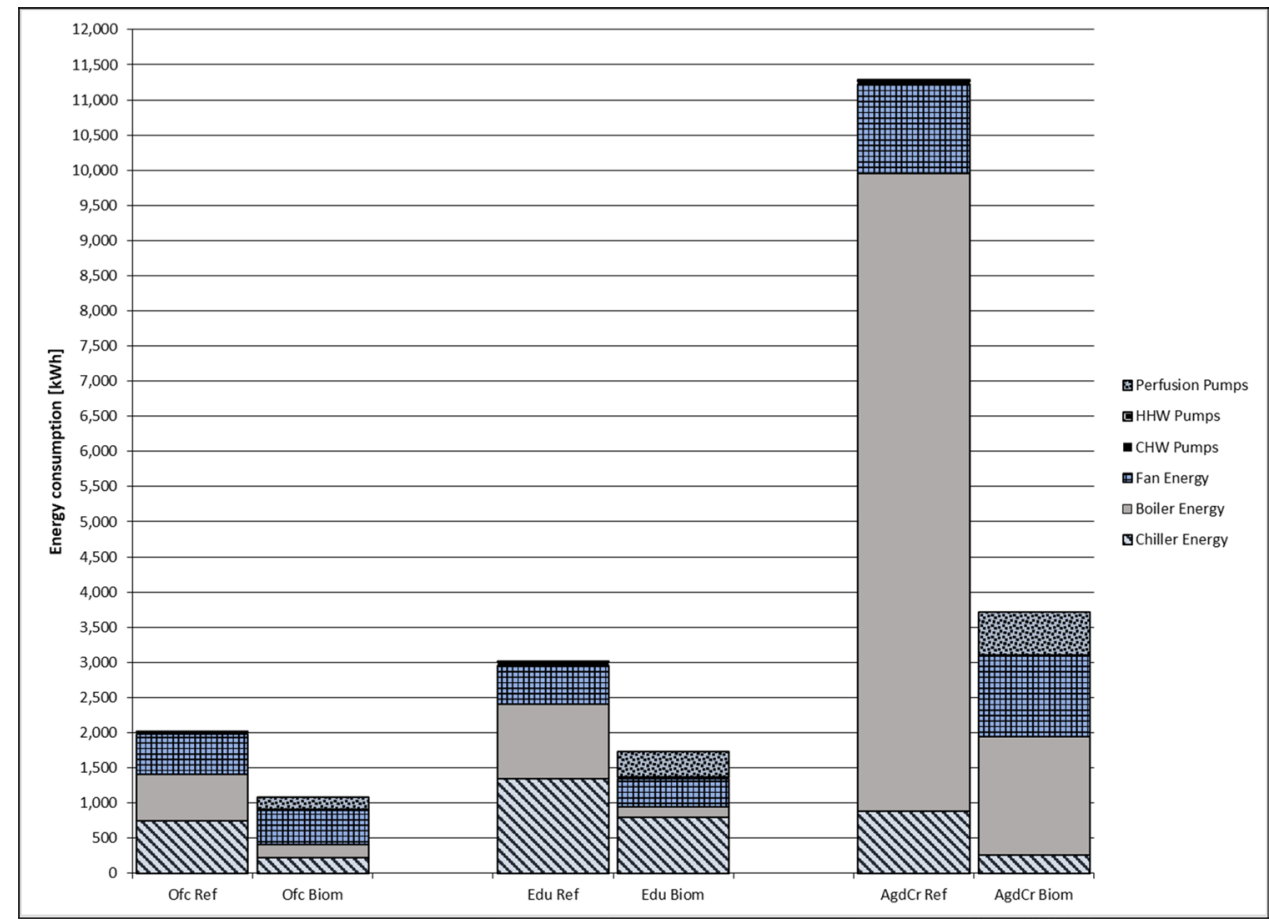

cooling and heating demand that was required for the space, throughout the year, normalised by floor area. The following charts indicate how the biomimetic facades performed in each of the climate zones with respect to peak heating and cooling loads. Figure 11 shows peak heating and cooling loads for the simulations with the biomimetic façade, including reference cases.

Reviewing the results for peak loads, there were similarities and differences across climate zones. In peak cooling, simulated peaks were similar for the biomimetic zones in three of the cases (Cfb, Dfb and Bwh), while the Aw (tropical) climate showed the lowest peak cooling demand. This was despite the tropical climate having the greatest annual cooling demand and again indicated the continuous nature of the cooling requirements in tropical climates. There was greater differentiation in the heating demand across climate zones, with the $\mathrm{Cfb}$ and $\mathrm{Bwh}$ zones having a similar peak demand, while the coldest climate had a demand that was three times greater than these cases. It was important to also note that peak loads presented here represent peak system requirements to meet the dynamic cooling or heating demand for the simulated annual weather file, and would differ from the design heating and cooling loads as calculated by a mechanical design engineer.

Comparing relative differences between the biomimetic designs and reference cases in each climate, the greatest reduction achieved was for cooling in the Aw climate, which can be attributed to the effect of perfusion cooling present in the biomimetic façade. The perfusion cooling made a substantial contribution to the overall cooling supply, reducing the requirement for air-based cooling that was required in the Aw reference case. In the Aw biomimetic case, efficiencies were obtained through water-based cooling, low volumes of water required (compared to an air-based solution) plus a reduction in the fan energy required to deliver cooling to the occupied zones. In the Dfb case-a much colder climatethere was a much smaller difference between reference and biomimetic cases for heating and cooling. The heating demand for the biomimetic case was actually greater in the Dfb case. This was due to the additional heating supplied by the perfusion system in the simulation, which would have provided additional heating to the space but also lost heat to the external environment, leading to a $2 \%$ increase in peak simulated heat demand. One potential option to reduce heat loss from perfusion would be to introduce an additional layer of solid insulation beneath the external fur layer, directing greater heat flow to the internal surface.

\section{Building types}

\section{Annual energy comparison: building types}

Similar to climate simulations, the building type comparison shows annual energy results for the biomimetic zone only. Figure 12 displays results for the annual services energy consumption for each of the building type simulations with the biomimetic façade, including reference cases. Table 9 provides a summary of all the results across the different building types, and Table 10 shows the reduction that each 
Table 9 Energy consumption for building type simulations

\begin{tabular}{|c|c|c|c|c|c|c|}
\hline \multirow[t]{2}{*}{ Energy category } & \multicolumn{2}{|c|}{ Office } & \multicolumn{2}{|c|}{ Education } & \multicolumn{2}{|c|}{ Aged care } \\
\hline & $\begin{array}{l}\text { Ofc } \\
\text { Ref }\end{array}$ & $\begin{array}{l}\text { Ofc } \\
\text { Biom }\end{array}$ & 1342 & 792 & $\begin{array}{l}\text { AgdCr } \\
\text { Ref }\end{array}$ & $\begin{array}{l}\text { AgdCr } \\
\text { Biom }\end{array}$ \\
\hline Chiller energy & 741 & 222 & 1065 & 155 & 886 & 256 \\
\hline Boiler energy & 665 & 188 & 543 & 392 & 9064 & 1690 \\
\hline Fan energy & 571 & 487 & 54 & 35 & 1276 & 1140 \\
\hline CHW pumps & 30 & 10 & 3 & 0 & 36 & 11 \\
\hline HHW pumps & 2 & 1 & 0 & 353 & 26 & 5 \\
\hline Perfusion pumps & 0 & 173 & 3007 & 1727 & 0 & 607 \\
\hline Total & 2008 & 1080 & 1342 & 792 & 11,288 & 3709 \\
\hline
\end{tabular}

Table 10 Biomimetic design reductions in energy for each building type

\begin{tabular}{llll}
\hline Energy category & Office $(\%)$ & Education $(\%)$ & Aged care $(\%)$ \\
\hline Chiller energy & -70 & -41 & -71 \\
Boiler energy & -72 & -85 & -81 \\
Fan energy & -15 & -28 & -11 \\
CHW pumps & -68 & -35 & -69 \\
HHW pumps & -72 & -85 & -81 \\
Perfusion pumps & na & na & na \\
Total & -46.2 & -42.6 & -67.1 \\
\hline
\end{tabular}

biomimetic design had over its respective reference case for each different building type.

Following the trend of the climate simulations, biomimetic designs showed reductions in the services energy across the three building types. Compared with the varied energy reductions across climate categories, the reductions in energy for each of the services components (cooling, heating, etc.) were similar between building types. There was one exception, however: the heating energy consumption for the Aged Care simulation, which showed a $7374 \mathrm{kWh}$ reduction from the reference case, compared with less than $1000 \mathrm{kWh}$ reduction in the Education and Office simulations. The main contributing factor to this result is the extended operational schedule for Aged Care facilities, which run $24 \mathrm{~h}$ per day and require constant conditioning for residents-particularly for heating results in a temperate climate. Therefore, the improved insulation benefits of the fur-lined façade had a greater impact. Apart from in heating energy, the absolute reductions in energy were similar, for fans, chillers and pumps.

In terms of a proportional comparison, the reductions observed for the biomimetic cases did show some differences. For example, while all three boiler energy reductions were $80 \% \pm 10 \%$, the chiller (cooling) reductions in the Education case was $41 \%$, while in the Office and Aged Care cases, the reduction was around $70 \%$. The lower reduction in cooling for the Education case was the nature of the internal loads, with the Education case having a much larger occupancy. The high occupancy of $2 \mathrm{~m}^{2}$ per person resulted in internal loads being $87 \%$ higher in the Education case compared to the Office case. The additional occupancy also required air for occupant ventilation, and necessitating a higher conditioning demand for outside air. The inclusion of a high-performance biomimetic façade could not affect the conditioning requirement for outside air, and this illustrated one of the limitations of the proposed design. It was apparent that the biomimetic façade would be more effective at reducing services energy consumption in building types where envelope heat loads dominated the load profile, rather than occupant loads and outside air. There was a higher proportional reduction in fan energy in the Education (28\%) case compared with the Office (15\%) and Aged Care $(11 \%)$ cases. This result followed from the climate zone studies, which suggested that insulation building envelope strategies would have a limit to their effectiveness if internal loads and insulation were not improved as well.

\section{Peak heating and cooling comparison: building types}

Figure 13 shows the peak heating and cooling loads for the building type simulations with the biomimetic façade, including reference cases.

Absolute peak heating and cooling was relatively similar for the three building types, although the higher internal loads in the Education case drove a higher cooling demand. The heating demand peaks in the Education and Aged Care simulations were lower than the baseline Office case. The Education case was lower because of a later start time in the assumed schedule (09:30) compared to the office (08:30) and would operate with higher internal loads. The Aged Care case was assumed to operate continuously, and would therefore not need to start up from a cold, unoccupied building (noting again that these were dynamic peak loads and not design peak loads).

In comparing the effect of the biomimetic façade on the peak loads across the building types, it was observed that the proportional cooling reduction achieved through the 
Fig. 13 Peak heating and cooling for different climates-comparison

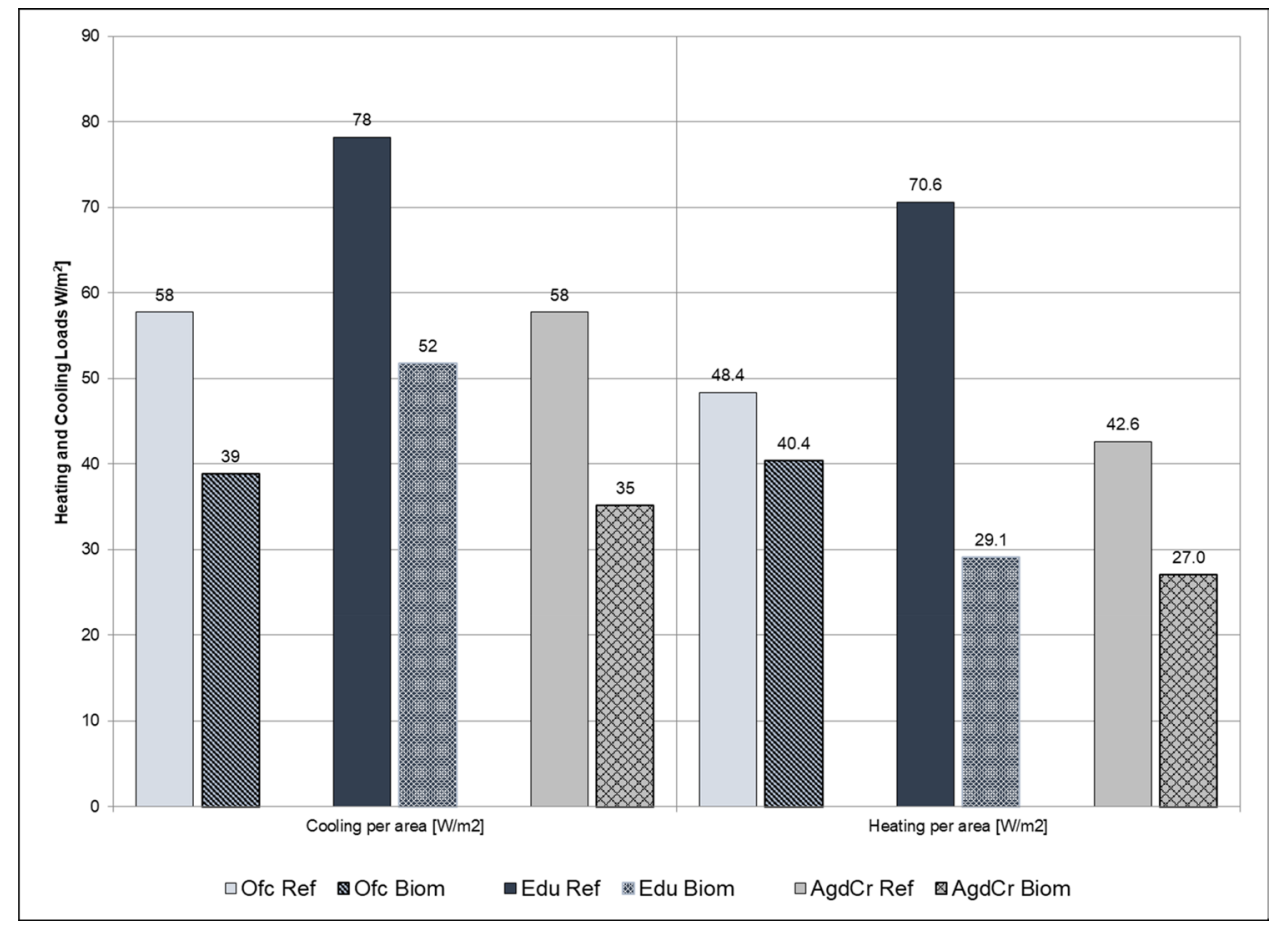

biomimetic façade was similar for all three cases, with a $35 \% \pm 5 \%$ decrease in cooling when compared with the reference case. In heating, there was more of a difference in the building types, with a $17 \%$ reduction in offices, $60 \%$ reduction in the Education case and $37 \%$ reduction in the Aged Care case. The large reduction in the Education case could be attributed to the retention of internal heat from occupants due to an improved external insulation from the fur lining. In the Aged Care case, the better performance of the biomimetic façade was due to the efficiency of the perfusion system to deliver heating via hot water perfusion through the building envelope, which, once reaching the maximum allowable temperature, would have created only small ongoing demand due to losses to the external environment through a well-insulated, fur-lined, external façade. The results for the Education and Aged Care facilities illustrated the effectiveness of the additional insulation provided by the fur layer and the efficient form of space heating achieved through perfusion through the façade. This would be especially applicable climates where heating demand is significant, such as the Cfb climate tested (Melbourne Australia) and in colder climates, such as the Dfb climate (e.g. Stockholm, Sweden).

\section{Comparison with simulation and energy reduction studies}

This study was undertaken to simulate the potential effect of biomimetic facades with the aim to decrease energy consumption in buildings of different type in different climate zones. To place the results of the study in context with other research, a review was conducted on other simulation studies where energy-saving initiatives have been proposed for buildings in different climate zones, with an emphasis on innovations for building envelopes or performance improvements in HVAC systems. A summary of comparative studies is indicated in Table 11.

The energy simulation studies noted in Table 11 may be further summarised by climate zone building type and energy reduction. This comparison was completed and compared against an equivalent summarisation of the scenarios tested in the current assessment of biomimetic facades, as shown in Table 12. Note: for additional data points, individual scenario outcomes were separated in each reference paper, where possible.

Table 12 indicates a substantial difference in energy reduction achieved through the biomimetic design compared with alternative energy efficiency initiatives. A statistical comparison of the biomimetic scenarios against the sample of alternative studies using a t test of unequal variances suggests that there is a very low probability $(<0.001)$ that the energy reductions from these two groups are equal, i.e. the greater magnitude achieved by the biomimetic designs may be considered statistically significant. However, it was noted that both samples sizes were relatively small and future work is recommended to extend this comparison. 


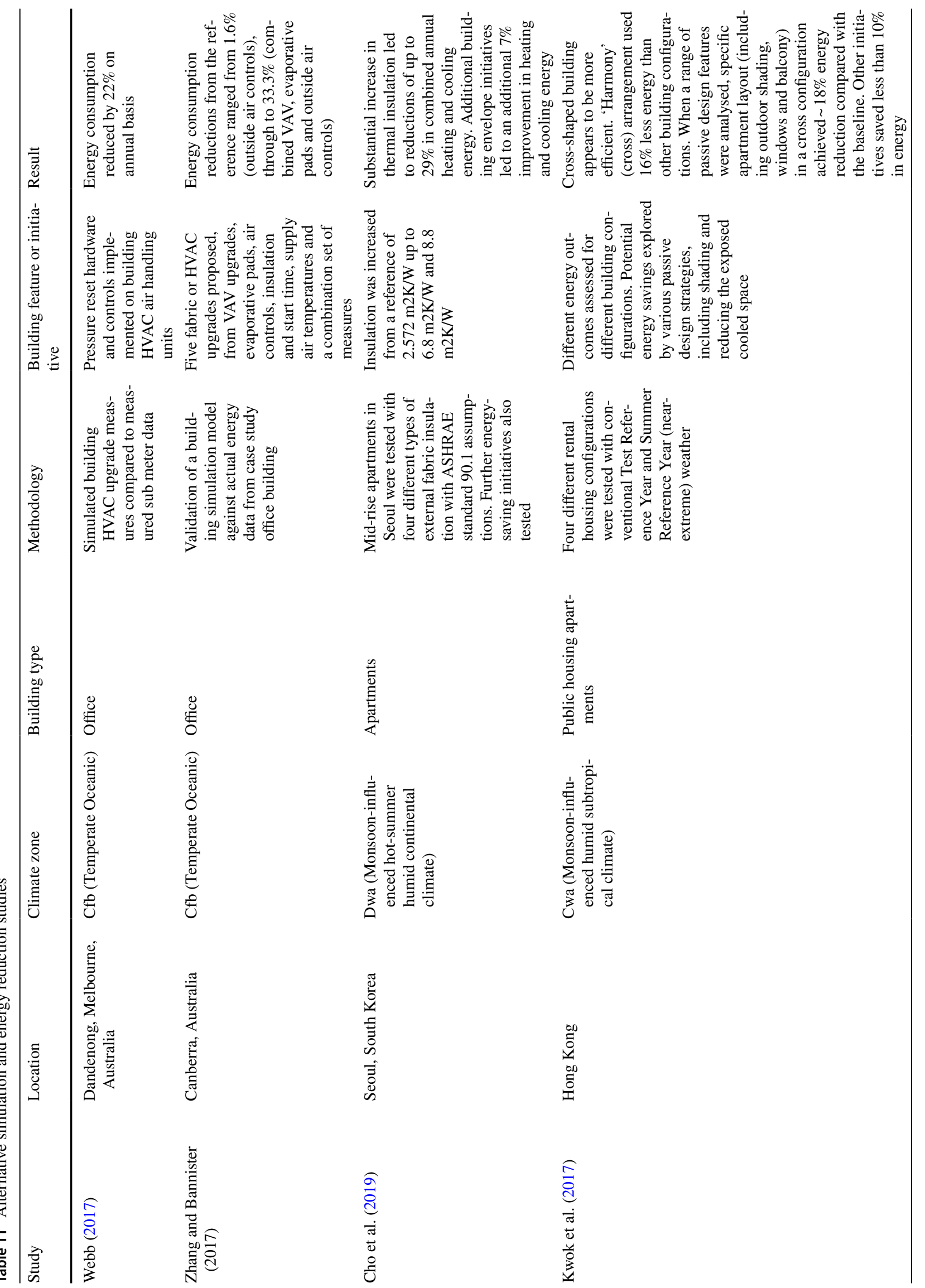




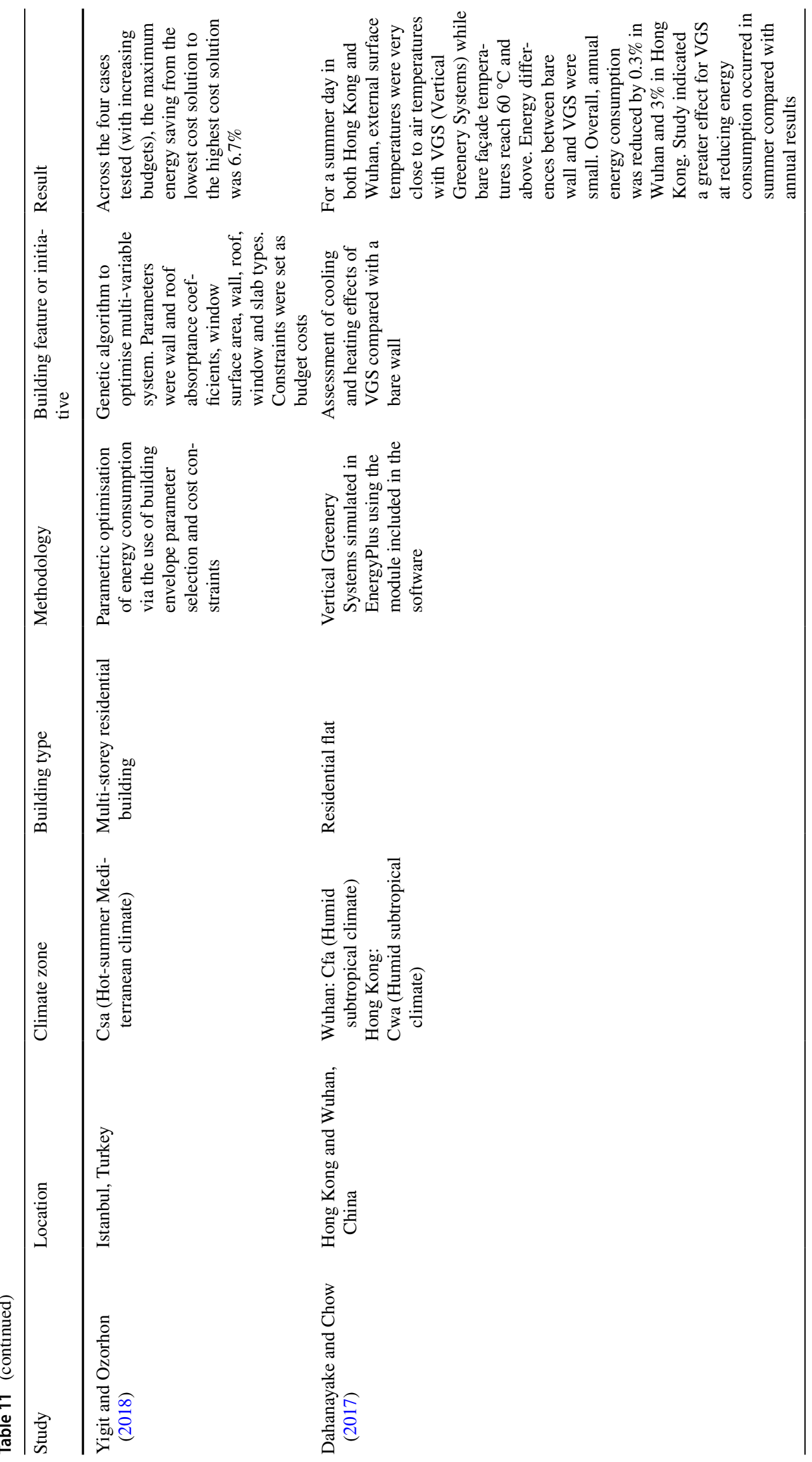




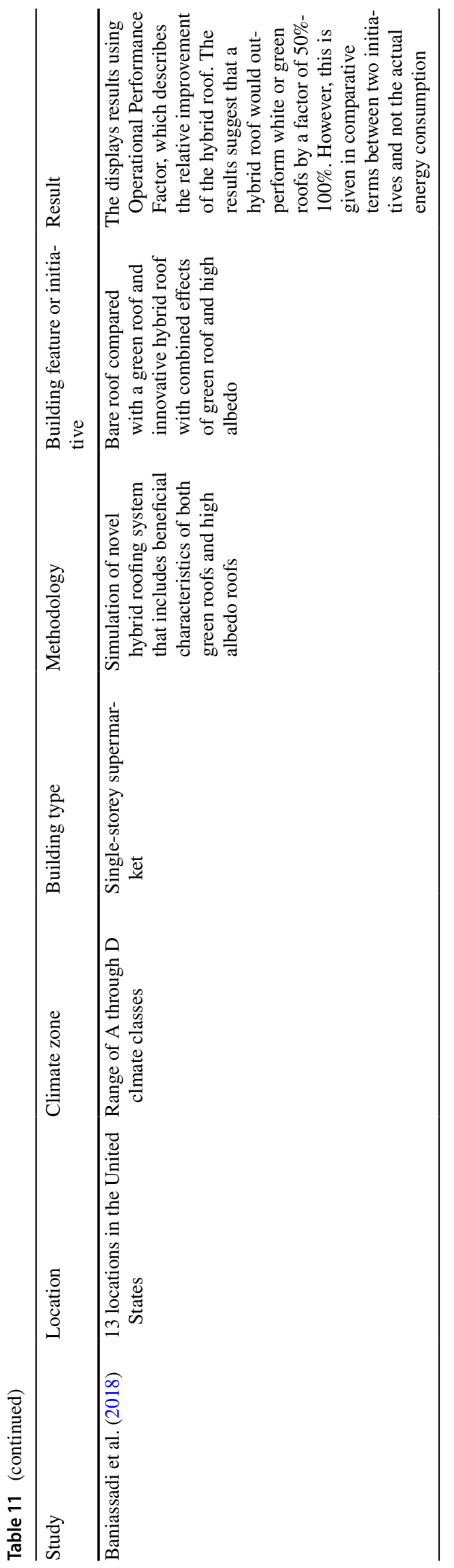

\section{Limitations and further work}

The basis preceding work showed the potential for biomimetic building facades as a means to reduce operational energy consumption and maintain thermal comfort for several climate zones and building types. This result was based on digital designs and modelling, which were subject to assumptions and limitations.

Building on this work, the biomimetic model could be further developed. There are opportunities to develop the model further to include additional effects and increase the accuracy of the Pennes bioheat equation, as in Cena and Monteith (1975a, b), He et al. (2011), Charny (1992), Weinbaum et al. (1997) and Jiji (2009). Furthermore, the modelling of animal tissue could be varied to account for differences in tissue physiology that are apparent in different species. Potential model frameworks include Parry (1949), Ackman et al. (1975), Lockyer et al. (1984, 1985); SchmidtNielsen (1997) and Liwanag (2008).

Furthermore, there are many examples of natural adaption to acute and seasonal weather variation. Such dynamic response represents a potentially powerful direction in which to further develop the biomimetic facades. There are also opportunities to adapt and optimise fur and perfusion properties to suit specific locations. Heating optimisation would benefit the results obtained for the Dfb climate, while in tropical climates, management of air moisture content is important. Preliminary heating optimisation preliminary heating optimisation study was conducted for a furlined façade during winter heating in Melbourne, Australia (Webb et al. 2011). Addtionally, nature-inspired initiatives to remove moisture from the air could be investigated, e.g. trees that remove fog from the air (Goldsmith et al. 2013) and species of orchid that absorb moisture from a humid atmosphere (Zotz and Winkler 2013).

As highlighted in the results, it was apparent that the performance improvement achieved by the biomimetic façade was dependent upon the load balance. When building envelope loads were dominant, the greatest energy reductions were achieved. However, in situations with lower impact of building envelope heat loads, smaller energy reductions were achieved by the biomimetic facades. Additional investigation may be conducted to identify nature-inspired characteristics to improve latent heat management and ventilation heat exchange. For example, respiratory heat exchange in vertebrates Schmidt-Nielsen et al. (1970), counter current heat exchange in elephant seals (Huntley et al. 1984) and brain heat flow management in Thomson's gazelles (Taylor and Lyman 1972).

The comparison between biomimetic facades and alternative energy efficiency initiatives indicated that biomimetic designs could achieve a significantly greater energy 
Table 12 Alternative simulation and energy reduction studiesresults summary

\begin{tabular}{|c|c|c|c|}
\hline Study & Building type & Climate & $\begin{array}{l}\text { Energy consump- } \\
\text { tion reduction } \\
(\%)\end{array}$ \\
\hline \multicolumn{4}{|c|}{ Alternative energy simulation studies } \\
\hline Webb (2017) & Office & $\mathrm{Cfb}$ & -22 \\
\hline Zhang and Bannister (2017) & Office & $\mathrm{Cfb}$ & -1.60 \\
\hline Zhang and Bannister (2017) & Office & $\mathrm{Cfb}$ & -33.30 \\
\hline Cho et al. (2019) & Apartments & Dwa & -29 \\
\hline Cho et al. (2019) & Apartments & Dwa & -36 \\
\hline Kwok et al. (2017) & Apartments & Cwa & -18 \\
\hline Kwok et al. (2017) & Apartments & Cwa & -16 \\
\hline Yigit and Ozorhon (2018) & Multi-residential & Csa & -6.70 \\
\hline Dahanayake and Chow (2017) & Apartments & $\mathrm{Cfa}$ & -3 \\
\hline \multirow[t]{2}{*}{ Dahanayake and Chow (2017) } & Apartments & Cwa & -3 \\
\hline & & Mean for alternative studies & -16.86 \\
\hline \multicolumn{4}{|l|}{ Scenarios tested in current study } \\
\hline Climate zone biomimetic & Office & $\mathrm{Dfb}$ & -55.1 \\
\hline Climate zone biomimetic & Office & Bwh & -49.4 \\
\hline Climate zone biomimetic & Office & Aw & -55.4 \\
\hline Building type biomimetic & Office & $\mathrm{Cfb}$ & -46.2 \\
\hline Building type biomimetic & Educational & $\mathrm{Cfb}$ & -42.6 \\
\hline \multirow[t]{2}{*}{ Building type biomimetic } & Aged care & $\mathrm{Cfb}$ & -67.1 \\
\hline & & $\begin{array}{l}\text { Mean for scenarios tested in } \\
\text { current study }\end{array}$ & -52.6 \\
\hline
\end{tabular}

reduction. However, the sample size for alterative studies was small, and not all climate zones or building types were included. Still, the biomimetic scenarios showed similar performance results regardless of the building or climate category.

Furthermore, this study relied on digital modelling and simulation. TRNSYS software is based on fundamental numerical modelling techniques and has been a key component of testing and development of the validation method for building simulation software, ASHRAE Standard 1402017 Standard Method of Test for the Evaluation of Building Energy Analysis Computer Programs (ASHRAE 140-2017 2017). It has been shown to be an effective simulation tool for built environment studies, with widespread use in numerous publications (Papers and Validation-Journals with References to TRNSYS). However, digital modelling is subject to assumptions and simplifications. Future efforts will focus on fabrication of physical prototypes for validation testing to test the conclusions drawn in this study.

Materials and fabrication form an important pillar of future work. Industry 4.0 (Stock and Seliger 2016) provides opportunities for waste minimisation, recycling and dematerialisation (Brownell 2008). However, advanced manufacturing - though digital fabrication and rapid prototypingoffers capability to deliver complexity and precision required to manufacture the proposed biomimetic facades. New fibres such as Vectran (Vectran 2010), a liquid crystal polymer, demonstrate the possible properties for durable fibrous materials required for the biomimetic façade. New 3D printing technology (Ngo et al. 2018) can provide precision manufacturing necessary to fabricate the façade. This includes the precision required to create the structures necessary for fur fibres and the perfusion materials (Zhang et al. 2017). Additive manufacturing has recently been tested on a full-scale façade module (Mungenast 2021) and provides opportunities to improve sustainability (Ford and Despeisse 2016).

This study focussed on the performance capability potential for a biomimetic building skin. Further work is necessary to understand the economic feasibility of such building initiatives. While, as noted in the Introduction, there have been studies that have investigated applications of biomimicry to architecture and building skins, little emphasis has been placed on the economic feasibility and constructability. Exploration architecture have proposed a high-performance office building employing a number of biomimetic features; however, the project remains at a design stage (The Biomimetic Office Building 2021). Chayaamor-Heil and Hannachi-Belkadi (2017) proposed a Bayesian Network as a method to organise complex decisions involved in applying biomimicry to building design; however, they focussed technical requirements rather than economic considerations. Broader studies have suggested an increasing development and application of biomimetic innovation in multiple industrial sectors; however, there is a gap in research on specific 
economic feasibility of specific biomimetic initiatives for architecture. Smith et al. (2015) identify biomimicry as a burgeoning innovation opportunity, and identifies research, development and production in nine industrial sectors, noting that developments in carbon, water, materials, energy conversion and storage, fluid dynamics, data and computing and systems analysis all have potential application to buildings. However, these technologies, especially those currently in development or available in the market are mostly component and materials-based. The study does not investigate these technologies in the context of a construction project. In the same study, the authors site research by Fermanian Business and Economic Institute estimated that bioinspiration could account for $\$ 425$ billion in US GDP and 2 million jobs. A large proportion of benefit is estimated for the building sector (approximately $\$ 70$ million) however feasibility of individual technologies is not specified.

Other researchers have investigated the funding, financing and policy incentives for sustainable, higher-performing buildings. For example, Diwekar (2015) suggests a more holistic perspective is required for engineering sustainability. Chen and Hong (2015) indicate that, from a Chinese perspective, subsidies do play a role in incentivising green buildings, and that improving information flow will contribute to more green building, while Staniškis and Stasiškienë (2003) presented a model for facilitating cleaner production incentives in developing countries. Finally, Muo and Azeez (2019) took a broad view of green entrepreneurship and the factors influencing businesses to maintain "businessas-usual practices", concluding that while benefits of green entrepreneurship are enormous and it has a role in creating a sustainable green economy, there are several concerns preventing more widespread adoption, such as inclusiveness and greenwashing. The authors suggest that change management should be a future focus for green entrepreneurship. The development of high-performance biomimetic façades must contend with these societal and economic conditions to be a viable option in future construction. Opportunities should be sought for governmental green financing and newer investment pathways.

\section{Conclusions}

Society must rapidly decrease carbon emissions to mitigate dangerous climate change. Since buildings consume a significant proportion of energy, drawn from carbon-intensive electricity grids, improving energy efficiency is a necessary step. With the development of active façade technology, smart buildings and Industry 4.0, applications of biomimicry can achieve further energy and carbon reductions. Biomimicry- "innovation inspired by nature"- -has been adopted in multiple technological and engineering fields as a framework for innovation and improvement. This study tested the hypothesis that the animal fur-perfusion façade design would reduce building services energy consumption in different building types and varying climates at least as much as shown for offices in a temperate climate. Modelling demonstrated the hypothesis to be confirmed. Results showed the biomimetic façade had strong potential to reduce operational energy consumption in the order of $50 \%$ for all different climate zones and in all building types. Furthermore, with one exception (heating in Dfc climate zone), the biomimetic façade showed a decrease in dynamic peak heating and cooling demand, again by up to $50 \%$. The physical characteristics of the fur lining to provide extra insulation and a barrier to incoming solar radiation, in combination with the water-based perfusion inside the façade, were effective in improving the building envelope energy efficiency.

Energy efficiency and peak heating and cooling loads varied across the climate zones and building types. In each alternative climate zone, the percentage energy reduction achieved over a reference baseline was greater than in the original study for a $\mathrm{Cfb}$ climate. The greatest percentage decrease was achieved in the tropical Aw climate (3112 kWh, or 55.4\%). When testing peak cooling, the tropical Aw climate also had the greatest reduction of $51 \%$. In all of the climate zones, the magnitude of the energy decrease was greater than that for the baseline, temperate, $\mathrm{Cfb}$, climate zone.

Across building types, the Aged Care simulation showed the greatest potential for energy savings, with a $67.1 \%$ reduction over the reference, the Education type indicated a $42.6 \%$ reduction compared with the original Office study at $46.2 \%$. As for climate zones, results substantiated the study hypothesis. There was a significant improvement in heating efficiency in all three building types, owing to the insulative effect of the building fur and efficient water-based heat transfer from perfusion.

The proposed fur-perfusion façade was compared to other energy simulation studies focussed on building envelope energy efficiency or upgrades. This comparison indicated that the fur-perfusion facade performed statistically better in energy reduction than alternatives; however, the sample size was limited.

These results confirmed the study hypothesis that the biomimetic façade design would improve energy efficiency and reduce peak demand in different climate zones and building types. Both findings were significant in both environmental and economic terms. Building operational energy savings equate to lower supply from carbon-intensive electricity grids and cost savings for building owners. Reductions in peak demand reduce pressure on peak capacity on electrical infrastructure, which can lead to carbon intensification of electricity supply and more greenhouse gas emissions. 
Peak demand reduction also reduces peak demand tariffs for owners, delivering more significant cost savings.

Using this case study, the research has demonstrated the potential for biomimetic facades to have a substantial impact on the performance of building envelopes to decrease energy consumption and peak demand across multiple climate zones and building types, leading to reductions in carbon emissions and lower demand on electrical infrastructure. Additionally, the research demonstrated viable mathematical modelling and building simulation methods that could be applied for alternative biomimetic initiatives for building facades. Further work to investigate the production and manufacture, physical validation and economic feasibility will strengthen the case for application of the fur-perfusion facades to decrease the energy and carbon footprint of buildings, while contributing economic advantages and sustainability of building materials.

Authors' contributions Not applicable.

Funding Not applicable.

Data availability Data on results is available upon request.

Code availability Software code is not openly available; however, the author is willing to discuss the modelling protocols in detail with interested parties.

\section{Declarations}

Conflict of interest The authors declare that they have no conflict of interest.

\section{References}

ASHRAE 140-2017 (2017) ASHRAE, <https://www.techstreet.com/ standards/ashrae-140-2017?product_id=2001489>

ASHRAE Handbook-Fundamentals (2009) ASHRAE, Atlanta, USA

Ackman RG, Hingley JH, Eaton CA, Logan VH, Odense PH (1975) Layering and tissue composition in Blubber of Northwest Atlantic Sei Whale (Balaenoptera-borealis). Can J Zool 53(9):1340-1344

Al-Hazmy MM (2006) Analysis of coupled natural convection-conduction effects on the heat transport through hollow building blocks. Energy Build 38(5):515-521

Al-Obaidi KM, Azzam Ismail M, Hussein H, Abdul Rahman AM (2017) Biomimetic building skins: an adaptive approach. Renew Sustain Energy Rev 79:1472-1491

Aldersey-Williams H (2003) Zoomorphic-new animal architecture. Laurence King Publishing Ltd, London

Asdrubali F, D'Alessandro F, Schiavoni S (2015) A review of unconventional sustainable building insulation materials. Sustain Mater Technol 4:1-17

Australian Energy Update 2020 (2020) Department of Industry, Science, Energy and Resources, Canberra, ACT.

Badarnah L (2015) A biophysical framework of heat regulation strategies for the design of biomimetic building envelopes. Procedia Eng 118:1225-1235
Badarnah L (2017) Form follows environment: biomimetic approaches to building envelope design for environmental adaptation. Buildings 7(2)

Badarnah L (2012) Towards the Living Envelope-Biomimetics for building envelope adaption. $\mathrm{PhD}$ thesis, Technische Universiteit Delft

Baniassadi A, Heusinger J, Sailor DJ (2018) Building energy savings potential of a hybrid roofing system involving high albedo, moisture retaining foam materials. Energy Build 169:283-294

Benyus JM (1997) Biomimicry-innovation inspired by nature, Paperback. HarperCollins, New York

Bermejo-Busto J, Martin-Gomez C, Zuazua-Ros A, Ibañez-Puy M, Miranda-Ferreiro R, Baquero-Martin E (2016) Improvement of a peltier hvac system integrated into building envelopes implementing beehive strategies: a theory-based approach. DYNA 91(5):507-511

Bhushan B (2009) Biomimetics: lessons from nature-an overview. Philos Trans R Soc Math Phys Eng Sci 367(1893):1445-1486

Brownell B (ed) (2008) Transmaterial 2-a catalog of materials that redefine our physical environment, 1st edn. Pinceton Architectural Press, New York

Cena K, Monteith JL (1975a) Transfer processes in animal coats. I. Radiative transfer. Proc R Soc Lond B 188:377-393

Cena K, Monteith JL (1975b) Transfer processes in animal coats. II. Conduction and convection. Proc R Soc Lond B 188:413-423

Charny CK (1992) Mathematical models of bioheat transfer. In: Young IC (ed) Advances in heat transfer, vol 22. Elsevier, Amsterdam, pp 19-155

Chayaamor-Heil N, Hannachi-Belkadi N (2017) Towards a platform of investigative tools for biomimicry as a new approach for energyefficient building design. Buildings 7(4):19

Chen W, Hong X (2015) Design of effective subsidy policy to develop green buildings: from the perspective of policy benefit. Clean Technol Environ Policy 17(4):1029-1038

Cho HM, Park JH, Wi S, Chang SJ, Yun GY, Kim S (2019) Energy retrofit analysis of cross-laminated timber residential buildings in Seoul, Korea: Insights from a case study of packages. Energy Build 202:109329

Craig S, Grinham J (2017) Breathing walls: The design of porous materials for heat exchange and decentralized ventilation. Energy Build 149:246-259

Craig S, Harrison D, Cripps A, Knott D (2008) BioTRIZ suggests radiative cooling of buildings can be done passively by changing the structure of roof insulation to let longwave infrared pass. J Bionic Eng 5(1):55-66

Dahanayake KWDKC, Chow CL (2017) Studying the potential of energy saving through vertical greenery systems: using EnergyPlus simulation program. Energy Build 138:47-59

Davis LB, Birkebak RC (1974) On the transfer of energy in layers of fur. Biophys J 14:249-268

Diwekar U (2015) Perspective on pursuit of sustainability: challenges for engineering community. Clean Technol Environ Policy 17(7):1729-1741

Du Q, Bao T, Li Y, Huang Y, Shao L (2019) Impact of prefabrication technology on the cradle-to-site $\mathrm{CO} 2$ emissions of residential buildings. Clean Technol Environ Policy 21(7):1499-1514

Elkhayat YO, Ibrahim MG, Tokimatsu K, Ali AAM (2020) A comparative life cycle assessment of three high-performance glazing systems for office buildings in a hot desert climate zone. Clean Technol Environ Policy 22(7):1499-1515

Fecheyr-Lippens D, Bhiwapurkar P (2017) Applying biomimicry to design building envelopes that lower energy consumption in a hothumid climate. Archit Sci Rev 60(5):360-370

Ford S, Despeisse M (2016) Additive manufacturing and sustainability: an exploratory study of the advantages and challenges. J Clean Prod 137:1573-1587 
GBCA (2020) Green Star, GBCA, viewed 25 Nov 2020. <https://new. gbca.org.au/green-star/>.

Gebremedhin KG, Wu B (2001) A model of evaporative cooling of wet skin surface and fur layer. J Therm Biol 26(6):537-545

Goldsmith GR, Matzke NJ, Dawson TE (2013) The incidence and implications of clouds for cloud forest plant water relations. Ecol Lett 16(3):307-314

Gordon JE (1984) The new science of strong materials, or, Why you don't fall through the floor, 2nd edn. Princeton University Press, Princeton

Gruber P (2011) Biomimetics in architecture-architecture of life and buildings. Springer, Berlin

Gruber P, Gosztonyi S (2010) Skin in architecture: towards bioinspired facades. WIT Trans Ecol Environ 138:503-513

Haase M (2008) Double-skin facades for Hong Kong', PhD thesis, The University of Hong Kong. <http://hdl.handle.net/10722/55157>

Hamza N (2008) Double versus single skin facades in hot arid areas. Energy Build 40(3):240-248

Handbook for estimating NABERS Ratings (2019) NSW Office of Environment and Heritage, viewed 08 Jan 2020. <https://www.nabers. gov.au/publications/commitment-agreement-documentation $>$.

He J, Hoyano A (2010) Experimental study of cooling effects of a passive evaporative cooling wall constructed of porous ceramics with high water soaking-up ability. Build Environ 45(2):461-472

He JH, Wang QL, Sun J (2011) Can polar bear hairs absorb environmental energy? Therm Sci 15(3):911-913

Heravi G, Salehi MM, Rostami M (2020) Identifying cost-optimal options for a typical residential nearly zero energy building's design in developing countries. Clean Technol Environ Policy 22(10):2107-2128

Hersey G (1999) The monumental impulse-architecture's biological roots. The MIT Press, Cambridge

Hoegh-Guldberg O, Jacob D, Taylor M, Bindi M, Brown S, Camilloni I, Diedhiou A, Djalante R, Ebi KL, Engelbrecht F, Guiot J, Hijioka Y, Mehrotra S, Payne A, Seneviratne SI, Thomas A, Warren R, Zho $\mathrm{G}$ (2018) Impacts of $1.5^{\circ} \mathrm{C}$ global warming on natural and human systems. In: Global warming of $1.5^{\circ} \mathrm{C}$. An IPCC Special Report on the impacts of global warming of $1.5^{\circ} \mathrm{C}$ above pre-industrial levels and related global greenhouse gas emission pathways, in the context of strengthening the global response to the threat of climate change, sustainable development, and efforts to eradicate poverty. International Panel on Climate Change, $<$ https://www.ipcc.ch/sr15/>.

Holman JP (2001) Heat transfer-Eighth SI metric edition, 8th, Edition. McGraw-Hill, New York

Hossaini N, Hewage K, Sadiq R (2015) Spatial life cycle sustainability assessment: a conceptual framework for net-zero buildings. Clean Technol Environ Policy 17(8):2243-2253

Hu M, Qiu Y (2019) A comparison of building energy codes and policies in the USA, Germany, and China: progress toward the net-zero building goal in three countries. Clean Technol Environ Policy 21(2):291-305

Huntley AC, Costa DP, Rubin RD (1984) The contribution of nasal countercurrent heat exchange to water balance in the northern elephant seal, Mirounga angustirostris. J Exp Biol 113(1):447

Islam S, Bhat G (2019) Environmentally-friendly thermal and acoustic insulation materials from recycled textiles. J Environ Manag 251:109536

Jessica A, Preciado BR, Otten D, Nelson B, Martin MC, Greif R (2002) Radiative properties of polar bear hair. Paper presented to ASME 2002 international mechanical engineering congress and exposition-advances in bioengineering, Louisiana, USA, Nov 17-22. https://doi.org/10.1115/IMECE2002-32473.

Jiji LM (2009) Heat conduction, 3rd edn. Springer, Berlin

Kamble SS, Gunasekaran A, Gawankar SA (2018) Sustainable Industry 4.0 framework: a systematic literature review identifying the current trends and future perspectives. Process Saf Environ Prot $117: 408-425$
Khan IS, Ahmad MO, Majava J (2021) Industry 4.0 and sustainable development: a systematic mapping of triple bottom line, circular economy and sustainable business models perspectives. J Clean Prod 297:1255

Kim KW, Olsen BW (2015) Radiant heating and cooling systems. ASHRAE J

Knaack U, Klein T, Bilow M, Auer T (2007) Facades—principles of construction. Birkhäuser Verlag AG, Basel

Kumar G, Thakur B, De S (2021) Energy performance of typical large residential apartments in Kolkata: implementing new energy conservation building codes of India. Clean Technol Environ Policy

Kuru A, Fiorito F, Oldfield P, Bosner SP (2018) Multi-functional biomimetic adaptive façades: a case study. Paper presented to FAÇADE 2018. Final conference of COST TU1403 "Adaptive Facades Network", Lucerne, Switzerland

Kwok YT, Lai AKL, Lau KK-L, Chan PW, Lavafpour Y, Ho JCK, Ng EYY (2017) Thermal comfort and energy performance of public rental housing under typical and near-extreme weather conditions in Hong Kong. Energy Build 156:390-403

Lee E, Selkowitz S, Bazjanac V, Inkarojrit V, Kohler C (2002) High performance commercial building facades. University of California, Berkeley

Liu M, Wittchen KB, Heiselberg PK (2015) Control strategies for intelligent glazed façade and their influence on energy and comfort performance of office buildings in Denmark. Appl Energy 145:43-51

Living Building Challenge (2020) International living future institute, viewed 20 Jan 2020, <https://living-future.org/lbc/>

Liwanag HEM (2008) Fur versus blubber: a comparative look at marine mammal insulation and its metabolic and behavioral consequences. $\mathrm{Ph}$. D. thesis, University of California at Santa Cruz

Lockyer CH, McConnell LC, Waters TD (1984) The Biochemical-composition of Fin Whale Blubber. Can J Zool 62(12):2553-2562

Lockyer CH, McConnell LC, Waters TD (1985) Body condition in terms of anatomical and biochemical assessment of body-fat in northatlantic fin and sei whales. Can J Zool 63(10):2328-2338

Lucon O, DUr-V, Zain Ahmed A, Akbari H, Bertoldi P, Cabeza LF, Eyre N, Gadgil A, Harvey LDD, Jiang Y, Liphoto E, Mirasgedis S, Murakami S, Parikh J, Pyke C, Vilariño MV (2014) Buildings. In: Climate Change 2014: Mitigation of Climate Change. Contribution of Working Group III to the Fifth Assessment Report of the Intergovernmental Panel on Climate Change, Intergovernmental Panel on Climate Change, United States of America

Lydon GP, Hofer J, Svetozarevic B, Nagy Z, Schlueter A (2017) Coupling energy systems with lightweight structures for a net plus energy building. Appl Energy 189:310-326

López M, Rubio R, Martín S, Ben C (2017) How plants inspire façades. From plants to architecture: biomimetic principles for the development of adaptive architectural envelopes. Renew Sustain Energy Rev 67:692-703

Merli R, Preziosi M, Acampora A, Lucchetti MC, Petrucci E (2020) Recycled fibers in reinforced concrete: a systematic literature review. J Clean Prod 248:119207

Mohajerani A, Vajna J, Cheung THH, Kurmus H, Arulrajah A, Horpibulsuk S (2017) Practical recycling applications of crushed waste glass in construction materials: a review. Constr Build Mater 156:443-467

Mungenast M (2021) 3D printed future façade — experimental testing of a $3 \mathrm{~d}$-printed building envelope', paper presented to powerskin conference, Munich, 9 Apr 2021

Muo I, Azeez AA (2019) Green entrepreneurship: literature review and agenda for future research. Int J Entrepr Knowl 7(2)

National Construction Code BCA (2016) Volume 1, 2016, Australian Building Codes Board, Canberra, ACT, 2016.

Neymark J, Judkoff R (2008) International energy agency building energy simulation test and diagnostic method (IEA BESTEST) multi-zone 
non-airflow in-depth diagnostic cases: MZ320-MZ360, National Renewable Energy Laboratory.

Ngo TD, Kashani A, Imbalzano G, Nguyen KTQ, Hui D (2018) Additive manufacturing (3D printing): a review of materials, methods, applications and challenges. Compos B Eng 143:172-196

Ogunmakinde OE, Sher W, Egbelakin T (2021) Circular economy pillars: a semi-systematic review. Clean Technol Environ Policy

Papers and Validation - Journals with References to TRNSYS, The University of Wisconsin Madison, viewed 29 Mar 2021, <https://sel. me.wisc.edu/trnsys/validation/index.html>

Park JJ (2016) Adaptive biomimetic façades: compound bio-inspired design strategy for multi-functional stadiums. PhD thesis, University of Melbourne, viewed 2016/07/14, <http://hdl.handle.net/ $11343 / 111995>$

Parry DA (1949) The structure of whale blubber, and a discussion of its thermal properties. Q J Microscopical Sci 90(1):13-000

Passive House (2020) Passivhaus Institut GmbH, viewed 20 Jan 2020 , $<$ https://passivehouse.com/>

Patnaik A, Mvubu M, Muniyasamy S, Botha A, Anandjiwala RD (2015) Thermal and sound insulation materials from waste wool and recycled polyester fibers and their biodegradation studies. Energy Build 92:161-169

Pawlyn M (2011) Biomimicry in architecture. RIBA Publishing, London

Pedersen Zari M (2007) Biomimetic approaches to architectural design for increased sustainability. Paper presented to SB07, New Zealand

Peel MC, Finlayson BL, McMahon TA (2007) Updated world map of the Köppen-Geiger climate classification. Hydrol Earth Syst Sci 11(5):1633-1644

Pennes HH (1948) Analysis of tissue and arterial blood temperatures in the resting human forearm. J Appl Physiol 1(2):93-122

Poirazis H (2006) Double skin facades - a literature review, department of architecture and built environment. Division of Energy and Building Design, Lund University, Lund Institute of Technology, Lund

Residential and Commercial Emissions in the United States (2017) Center for Climate and Energy Solutions, viewed 03-Nov 2017. <https:// www.c2es.org/energy/use/residential-commercial>.

Rogelj J, Shindell D, Jiang K, Fifita S, Forster P, Ginzburg V, Handa C, Kheshgi H, Kobayashi S, Kriegler E, Mundaca L, Séférian R, Vilariño MV (2018) Mitigation Pathways Compatible with $1.5^{\circ} \mathrm{C}$ in the Context of Sustainable Development. In: Global Warming of $1.5^{\circ} \mathrm{C}$. An IPCC Special Report on the impacts of global warming of $1.5^{\circ} \mathrm{C}$ above pre-industrial levels and related global greenhouse gas emission pathways, in the context of strengthening the global response to the threat of climate change, sustainable development, and efforts to eradicate poverty. International Panel on Climate Change, $<$ https:// www.ipcc.ch/sr15/>

Schittich (Ed.) C, Schittich C, Lang W, Kripper R (2006) In detail—building skins. Detail edn, Series-in detail. Birkhäuser, Basel

Schleicher S, Lienhard J, Poppinga S, Speck T, Knippers J (2015) A methodology for transferring principles of plant movements to elastic systems in architecture. Comput Aided Des 60:105-117

Schmidt-Nielsen K (1997) Animal physiology_adaption and environment, 5th ed. Cambridge University Press, Cambridge

Schmidt-Nielsen K, Hainsworth FR, Murrish DE (1970) Counter-current heat exchange in the respiratory passages: effect on water and heat balance. Respir Physiol 9(2):263-276

Siddique R, Khatib J, Kaur I (2008) Use of recycled plastic in concrete: a review. Waste Manag 28(10):1835-1852

Smith C, Bernett A, Hanson E, Garvin C (2015) Tapping into nature, United States.

Staniškis JK, Stasiškienë Z (2003) Cleaner production financing: possibilities and barriers. Clean Technol Environ Policy 5(2):142-147

Stock T, Seliger G (2016) Opportunities of sustainable manufacturing in industry 4.0. Procedia CIRP 40:536-541
Taylor CR, Lyman CP (1972) Heat storage in running antelopesindependence of brain and body temperatures. Am J Physiol 222(1):114-117

The Biomimetic Office Building (2021) viewed 02 Apr 2021. <http:// www.exploration-architecture.com/projects/biomimetic-office-build ing $>$.

USGBC (2020) LEED Rating System, USGBC, viewed 20 Jan 2020. 2020, <https://www.usgbc.org/leed>

Vectran (2010) Kuraray Group, viewed 7 July2021, <https://www.kurar ay.com/products/vectran>

Vincent JFV, Bogatyreva OA, Bogatyrev NR, Bowyer A, Pahl A-K (2006) Biomimetics: its practice and theory. J R Soc Interface 3(9):471-482

Vincent JFV, Mann DL (2002) Systematic technology transfer from biology to engineering. Philos Trans Math Phys Eng Sci 360(1791):159-173

Walsberg GE (1988a) Consequences of skin color and fur properties for solar heat gain and ultraviolet irradiance in 2 mammals. J Compar Physiol B-Biochem Syst Environ Physiol 158(2):213-221

Walsberg GE (1988b) The significance of fur structure for solar heat gain in the rock squirrel, spermophilus-variegatus. J Exp Biol 138:243-257

Wang J, Ma Y, Zhang L, Gao RX, Wu D (2018) Deep learning for smart manufacturing: methods and applications. J Manuf Syst 48:144-156

Webb M, Aye L, Green R (2018) Simulation of a biomimetic façade using TRNSYS. Appl Energy 213:670-694

Webb M (2017) Building tuning using simulation—a practical case study. Paper presented to Australasian building simulation conference, Melbourne, Australia, 15-16 Nov 2017

Webb M (2018) Development and performance analyses of biomimetic building facades. $\mathrm{PhD}$ thesis, University of Melbourne, viewed 2018/06/06, <http://hdl.handle.net/11343/213407>

Webb M, Aye L, Green R (2013) Investigating potential comfort benefits of biologically-inspired building skins. Paper presented to building simulation 2013, Chambéry, France, 26 Aug 2013

Webb M, Aye L, Green R (2015) Investigating potential comfort benefits of biologically-inspired building skins. Paper presented to living and learning: research for a better built environment: 49th international conference of the architectural science association 2015, Melbourne, Australia, 10 Dec 2015

Webb M, Hertzsch E, Green R (2011) Modelling and optimisation of a biomimetic façade based on animal fur. Paper presented to building simulation 2011, Sydney, Australia, 14 Nov 2011

Weinbaum S, Xu LX, Zhu L, Ekpene A (1997) A new fundamental bioheat equation for muscle tissue: part I-blood perfusion term. J Biomech Eng 119(3):278-288

Wigginton M, Harris J (2002) Intelligent skins. Butterworth-Heinemann, Oxford

Yigit S, Ozorhon B (2018) A simulation-based optimization method for designing energy efficient buildings. Energy Build 178:216-227

Zhang H, Bannister P (2017) A calibrated simulation case study for an office building in canberra. Ecolibrium 16:44-51

Zhang Z, Provis JL, Reid A, Wang H (2014) Geopolymer foam concrete: an emerging material for sustainable construction. Constr Build Mater 56:113-127

Zhang Y, Zhang F, Yan Z, Ma Q, Li X, Huang Y, Rogers JA (2017) Printing, folding and assembly methods for forming 3D mesostructures in advanced materials. Nat Rev Mater 2(4):17019

Zotz G, Winkler U (2013) Aerial roots of epiphytic orchids: the velamen radicum and its role in water and nutrient uptake. Oecologia 171(3):733-741

Zuo J, Zhao Z-Y (2014) Green building research-current status and future agenda: a review. Renew Sustain Energy Rev 30:271-281

Publisher's Note Springer Nature remains neutral with regard to jurisdictional claims in published maps and institutional affiliations. 